\title{
Maybe So, Maybe Not: Canis lepophagus at Hagerman Fossil Beds National Monument, Idaho, USA
}

\author{
Kari A. Prassack ${ }^{1}\left[\right.$. Laura C. Walkup ${ }^{2}(0)$
}

Accepted: 22 November 2021 / Published online: 1 January 2022

This is a U.S. government work and not under copyright protection in the U.S.; foreign copyright protection may apply 2021

\begin{abstract}
A canid dentary is described from the Pliocene Glenns Ferry Formation at Hagerman Fossil Beds National Monument, south-central Idaho, USA. The specimen possesses traits in alliance with and measurements falling within or exceeding those of Canis lepophagus. The dentary, along with a tarsal IV (cuboid) and an exploded canine come from the base of the fossiliferous Sahara complex within the monument. Improved geochronologic control provided by new tephrochronologic mapping by the U.S. Geological Survey-National Park Service Hagerman Paleontology, Environments, and Tephrochronology Project supports an interpolated age of approximately 3.9 Ma, placing it in the early Blancan North American Land Mammal Age. It is conservatively referred to herein as Canis aff. C. lepophagus with the caveat that it is an early and robust example of that species. A smaller canid, initially assigned to Canis lepophagus and then to Canis ferox, is also known from Hagerman. Most specimens of Canis ferox, including the holotype, were recently reassigned to Eucyon ferox, but specimens from the Hagerman and Rexroad faunas were left as Canis sp. and possibly attributed to C. lepophagus. We agree that these smaller canids belong in Canis and not Eucyon but reject placing them within C. lepophagus; we refer to them here as Hagerman-Rexroad Canis. This study confirms the presence of two approximately coyote-sized canids at Hagerman and adds to the growing list of carnivorans now known from these fossil beds.
\end{abstract}

Keywords Canidae $\cdot$ Pliocene $\cdot$ Blancan $\cdot$ Tephrochronology $\cdot$ National Park Service (NPS)

\section{Introduction}

\section{Canidae}

Canidae include the Hesperocyoninae, Borophaginae, and Caninae. Hesperocyonines were small and omnivorous and persisted from the late Eocene through early Miocene in North America (Wang 1994). The small, omnivorous borophagines of the Oligocene diversified in the Miocene and Pliocene to include the massive-jawed genus Borophagus (Wang et al. 1999, 2004). These later "bone crushing dogs" may have had an ecological role similar to that of Old World hyaenids (Biknevicius and Ruff 1992). Borophagines spread from North America into Central America and went extinct

Kari A. Prassack

kari_prassack@nps.gov

1 Hagerman Fossil Beds National Monument, National Park Service, Hagerman, ID, USA

2 Tephrochronology Project, U.S. Geological Survey, Menlo Park, CA, USA by the early Pleistocene (Wang et al. 1999, 2004). The Caninae appeared in the early Oligocene of North America (Tedford et al. 2009) and remained small, fox-like generalists until the late Miocene, when they quickly diversified and spread into Eurasia (Montoya et al. 2009; Sotnikova and Rook 2010) and Africa (Morales et al. 2005; de Bonis et al. 2007; Geraads 2011), reaching South America by the late Pliocene (Prevosti et al. 2009). Only the Caninae (true canids) persist today.

Today, the Caninae are widespread and represented by at least 36 species from 13 genera (Sillero-Zubiri et al. 2004). This includes seven to nine species (and numerous subspecies) of the genus Canis (wolves, dogs, and allies). Similarities in canid morphology across closely related taxa (Prevosti et al. 2013; Chemisquy et al. 2019; Machado and Teta 2020) coupled with inbreeding (Way 2013; Fan et al. 2016; von Holdt et al. 2016; Gopalakrishnan et al. 2018; Pilot et al. 2018; Machado and Teta 2020), allometric plasticityparticularly in jaw morphology (Slater et al. 2009; Machado and Teta 2020), and great intraspecific phenotypic variability due to wide geographic dispersions with population variance 
across ecospace (Meiri and Dayan 2003; Meiri et al. 2005; Pilot et al. 2012; Martinez et al. 2013; O'Keefe et al. 2013; Schiaffini et al. 2019) can make discerning species of similarly sized extant canids difficult (Pocock 1935; Prevosti et al. 2013; Chetri et al. 2016; Heppenheimer et al. 2018; Zrzavý et al. 2018; Chemisquy et al. 2019; Machado and Teta 2020). Such ambiguities are reflected in our evolving understanding of Pliocene and Pleistocene canid phylogenetic systematics (Tedford et al. 2009; Lucenti and Rook 2020; Perri et al. 2021).

\section{Pliocene Caninae of North America}

The basal canid genus Eucyon (Tedford and Qiu 1996; Tedford et al. 2009) dates to the Miocene late Clarendonian and Miocene-Pliocene Hemphillian Land Mammal Ages of North America (Bell et al. 2004) and late Miocene localities of Eurasia and Africa (Rook 1992, 2009; Morales et al. 2005; Montoya et al. 2009; Sotnikova and Rook 2010; Werdelin et al. 2015). Eucyon has been considered a paraphyletic taxon of questionable validity, with some specimens subsequently referred to the Vulpini or Amphicyonidae (Werdelin et al. 2015). Eucyon davisi is considered basal to tribe Canini, while other members of this genus appear to align well with the wolf-like subtribe Canina (Zrzavý et al. 2018). Eucyon is generally thought to have given rise to Canis (Wang and Tedford 2007).

Eucyon and early Canis share many synapomorphies (Tedford et al. 2009) and several early species of Canis have been moved to Eucyon (Rook 1992; Spassov and Rook 2006). This includes the recent reassignment by Lucenti and Rook (2020) of Canis ferox to Eucyon ferox. This late Hemphillian to late early Blancan canid was first described by Miller and Carranza-Castañeda (1998) as intermediate in morphology to the smaller, more fox-like, and gracile Eucyon species and the typically larger, more robust Blancan Canis lepophagus. Lucenti and Rook (2020) left specimens identified as Canis ferox from the Hagerman Local Fauna of Idaho (Bjork 1970) and Rexroad Local Fauna of Kansas (Hibbard 1941) as Canis sp. and suggested its placement in Canis lepophagus or Canis sp. nov. due to a lack of key diagnostic features attributable to Eucyon.

The remaining definitive early member of Canis is the coyote-sized Canis lepophagus. Its mix of basal and derived traits places it intermediately between Eucyon and larger, later members of the genus Canis (Tedford et al. 2009). It is restricted to the (primarily late) Blancan with one early and one late early Blancan locality in Nevada and Nebraska, respectively (Tedford et al. 2009). Previous studies placed C. lepophagus as the direct or intermediary ancestor of the coyote, Canis latrans (Johnston 1938; Giles 1960; Bjork 1970; Kurtén 1974; Nowak 1979; Kurtén and Anderson 1980; Anderson 1984; Bever 2005) or wolf, Canis lupus
(Kurtén 1974; Nowak 1979, 2002, 2003; Kurtén and Anderson 1980). However, those extant canids share several traits absent in C. lepophagus (Tedford et al. 2009), and the Canis lineage leading to wolves and coyotes is now considered of Eurasian origin (Perri et al. 2021).

Tedford et al. (2009) placed later Blancan C. lepophagus as ancestral to the Canis thooides-Canis feneus-Canis cedazoensis jackal-like lineage. Zrzavý et al. (2018) placed C. lepophagus in a basal and likely paraphyletic group of stem Canina that included Canis ferox and Canis thooides leading to Canis arnensis, but with unresolved polytomies, leaving its monospecificity in question. Systematics of this and other early canines remain largely unresolved.

\section{Hagerman Fossil Beds National Monument (HAFO)}

The Pliocene fluvial-lacustrine Glenns Ferry Formation is a stratigraphic unit that extends across southwestern Idaho. The most fossiliferous area of this formation comprises the nearly 4,300 acres of Hagerman Fossil Beds National Monument (HAFO), National Park Service, near the town of Hagerman, Idaho (Fig. 1). The Glenns Ferry dates from at least 4.2 to 3.07 Ma at Hagerman (Neville et al. 1979; Hart and Brueseke 1999; Hart unpublished data). Pleistocene sediments of Tuana Gravel ( 1.9 Ma) and Yahoo Clay (poorly constrained, Malde 1982) occur as isolated outcrops in some areas of the monument, but these units have produced little to no fossil remains, respectively, and do not occur within the study areas discussed herein.

The Hagerman strata preserve a diverse Blancan fauna of nearly 200 species including mammals, birds, reptiles, amphibians, fishes, and invertebrates (McDonald 1993). The Carnivora are well represented with six families and, with this new canid, 19 species (Table 1). Notable carnivoran taxa include the enigmatic meline, Ferinestrix vorax (Bjork 1970), a Blancan-aged remnant of the Hemphillian ursid, Agriotherium (Samuels et al. 2009), and the oldest New World river otter, Lontra weiri (Prassack 2016).

\section{Canidae of the Hagerman Fossil Beds}

Bjork (1970) described two canids from the Hagerman fossil beds: Canis lepophagus, a canine (see also Nowak 1979) and Borophagus hilli, a borophagine. Tedford et al. (2009) reassigned most early Blancan specimens of C. lepophagus, including those from Hagerman and Rexroad (Hibbard $1941)$ to Canis ferox. As noted, C. ferox is now invalid with the holotype and most other specimens moved to Eucyon by Lucenti and Rook (2020). We concur with Lucenti and Rook (2020) that the smaller canids of both Hagerman and Rexroad do not belong in Eucyon and are more closely aligned with the genus Canis, but not with Canis 
Fig. 1 The location of Hagerman Fossil Beds National Monument in south-central Idaho, USA. Inset shows the outline of the monument boundary along the western bank of the Snake River, west of the town of Hagerman, with a star denoting the general area of the main fossil localities discussed in this paper

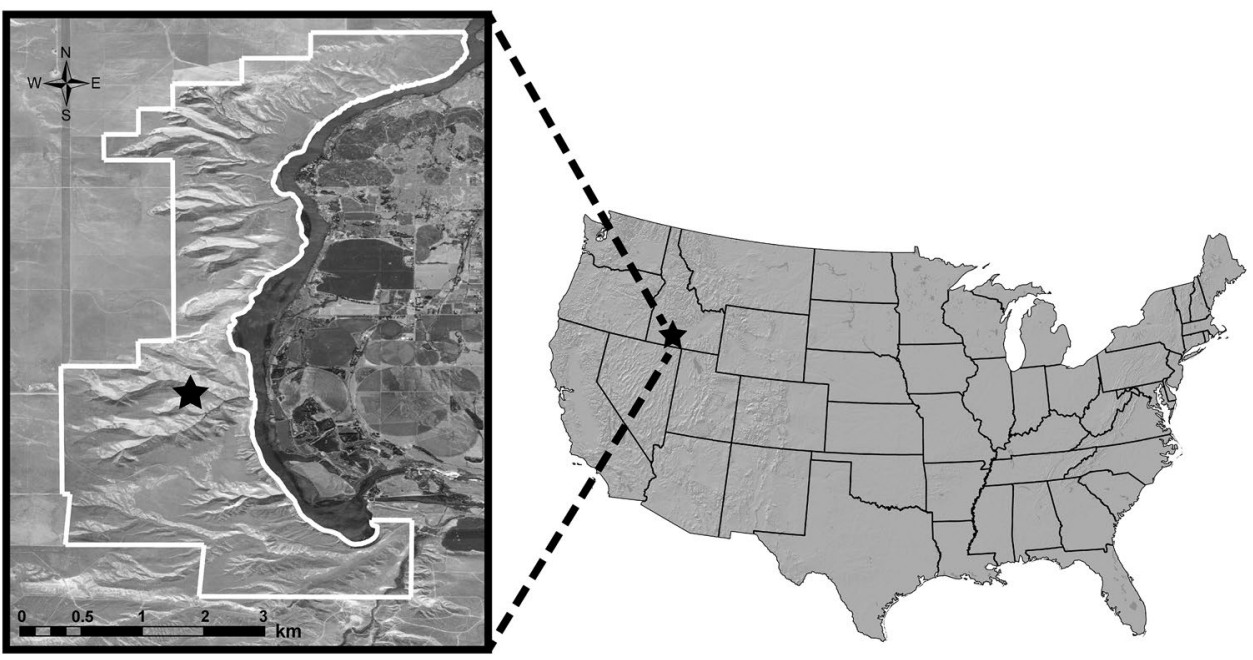

lepophagus. We herein refer to the Hagerman and Rexroad specimens as Hagerman-Rexroad Canis to differentiate those specimens from other canids discussed here.

Table 1 List of Carnivora known from the Hagerman Fossil Beds (Bjork 1970)

\begin{tabular}{|c|c|}
\hline Family & Taxon \\
\hline Canidae & $\begin{array}{l}\text { Borophagus hilli }^{a} \\
\text { Hagerman-Rexroad Canis } \\
\text { Canis aff. C. lepophagus }\end{array}$ \\
\hline Felidae & $\begin{array}{l}\text { Felis lacustris } \\
\text { Homotherium } \mathrm{sp} \text {. (previously Ischyrosmilus) } \\
\text { Lynx rexroadensis }^{\mathrm{d}} \\
\text { Meganteron hesperus (previously Machairodus) }\end{array}$ \\
\hline Mephitidae & Buisnictis breviramus \\
\hline Mustelidae & $\begin{array}{l}\text { Ferinestrix vorax } \\
\text { Lontra weiri }^{\text {e }} \\
\text { Mustela frenata (previously M. rexroadensis) } \\
\text { Satherium piscinarium } \\
\text { Sminthosinis bowleri } \\
\text { Taxidea taxus } \\
\text { Trigonictis cooki } \\
\text { Trigonictis macrodon }\end{array}$ \\
\hline Procyonidae & Procyon sp. ${ }^{\mathrm{f}}$ \\
\hline Ursidae & $\begin{array}{l}\text { Agriotherium c.f. schneideri } \\
\text { Ursus abstrusus }\end{array}$ \\
\hline
\end{tabular}

${ }^{\text {a Identified as Borophagus sp. by Bjork (1970) and assigned to B. hilli }}$ by McDonald (2020)

${ }^{\mathrm{b}}$ Identified as Canis lepophagus by Bjork (1970), Canis ferox by Tedford et al. (2009), Canis sp. by Lucenti and Rook (2020) and referred to here as Hagerman-Rexroad Canis

${ }^{\mathrm{C}}$ Specimens described in this paper

${ }^{\mathrm{d}}$ Werdelin (1985)

${ }^{\text {e}}$ Prassack (2016)

${ }^{\mathrm{f}} \mathrm{S}$. Wallace pers. comm.

${ }^{\mathrm{g}}$ Samuels et al. (2009)

\section{Site Description}

The primary specimen described herein is a robust canid dentary (HAFO 21175) collected within the Sahara complex in 2009 by a former HAFO paleontologist and a group of students and park staff. The Sahara complex is an east-facing bluff (Fig. 2) with a series of steep (50-75 ) exposures primarily along its eastern and southern flanks. The complex is named for a large sandy exposure colloquially referred to by park staff as the "Sahara blowout" that extends across a large swath of the major eroded eastern knob of the bluff.

Field notes from the day HAFO 21175 was collected do not indicate the depositional context or if the specimen was found in-situ, but coordinates collected with the specimen place it within an erosive sandy zone near the base of the complex (X in Figs. 2 and 3). This is along the western edge of HAFO locality 042 , a fossiliferous eight-meter exposed section of cross-bedded sand, silt, and clay. There, in-situ remains of Mammut americanum occur within a fining upward sequence of brownish gray coarse to medium lithic sand overlain by a thin lens of silty sand that contain a variety of microfauna (e.g., rodents, fish, frogs, and gastropods). Unfortunately, coordinates for HAFO 21175 are within GPS error of a wash that runs down the slope from just below the Sahara blowout to the collection site (Fig. 3). This initially prevented our confident placement of the specimen in this lower deposit.

Immediately above HAFO locality 042 are alternating angular blocky layers of beige and black clay and silty clay. Some fossils, primarily turtle shell fragments, have eroded out of these clay units, but a thick layer of overburden largely limits erosion. Continuing up the wall of the complex, an overlying covered interval of approximately $10 \mathrm{~m}$ is topped by an extensive bed of paper shales. These shales preserve abundant reed-like residues and carbon films and contain 


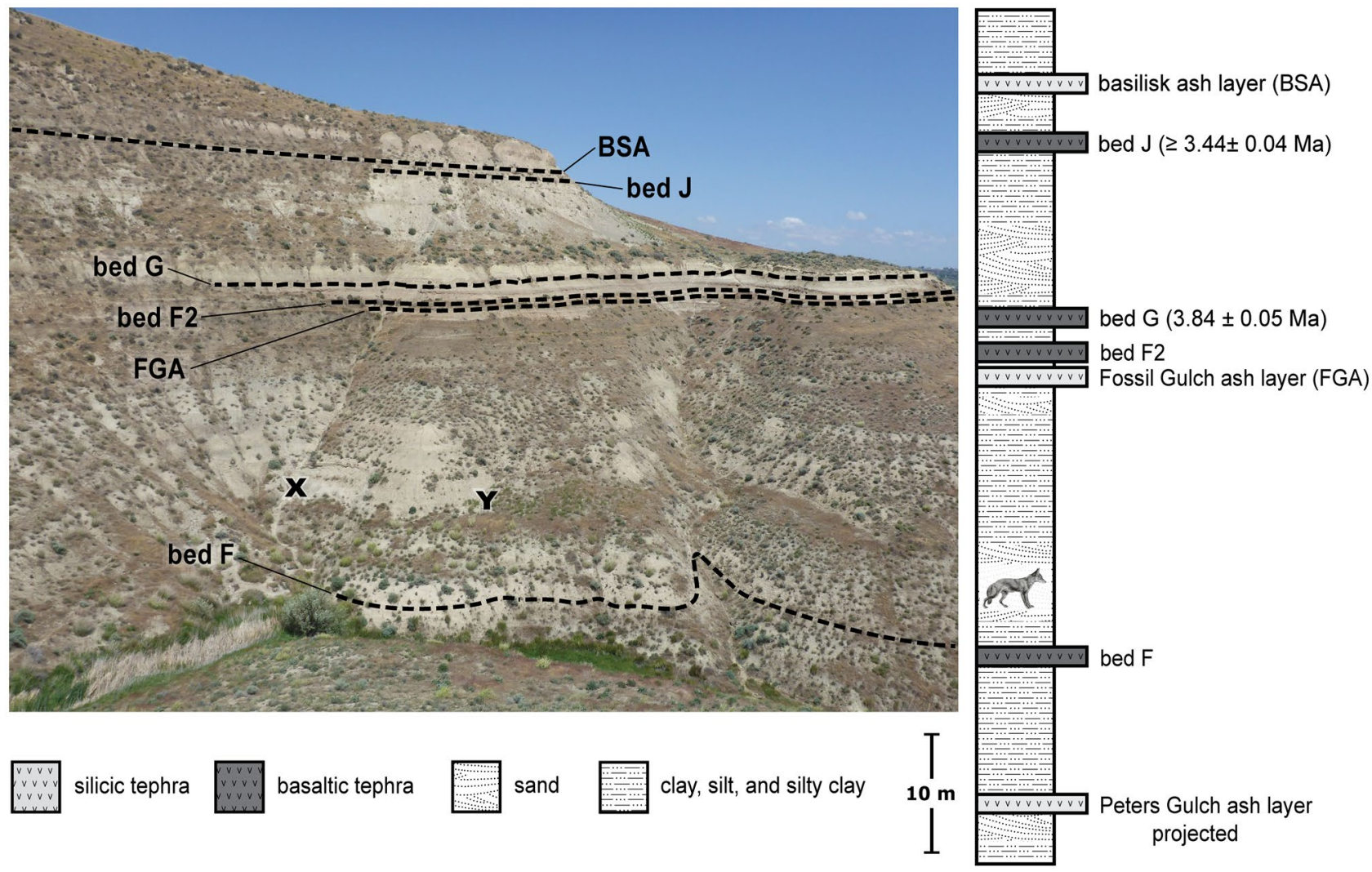

Fig. 2 The Sahara complex. Six tephra layers are directly mapped with a seventh projected from an adjacent bluff. Locations of HAFO 21175 (left, HAFO locality 042) and HAFO 26531 (right, HAFO locality 535) are marked by an X and Y, respectively. The canid icon shown in the right stratigraphic column represents the stratigraphic position of both fossil localities. The age shown for bed $\mathrm{G}$ is recal-

several volcanic tephra layers, including a basaltic tephra informally named bed G (Malde and Powers 1962) that is dated at $3.84 \pm 0.05 \mathrm{Ma}\left({ }^{40} \mathrm{Ar} /{ }^{39} \mathrm{Ar}\right.$, recalculated) (Hart and Brueseke 1999). Overlying the paper shales, the Sahara blowout is comprised of thick beds of poorly consolidated sand interspersed with thin layers of clay. A wide range of fossil taxa have come from the eastern flank of this upper sandy unit while comparatively few fossils erode out of its steeper southern face that lies directly above HAFO locality 042. Another basaltic tephra, bed J, overlies these sands and directly underlies the $3.44 \pm 0.04 \mathrm{Ma}\left({ }^{40} \mathrm{Ar} /{ }^{39} \mathrm{Ar}\right.$, recalculated) Deer Gulch lava flow (Hart and Brueseke 1999) in the northern end of the monument. If HAFO 21175 originated from these upper deposits, rather than the stratigraphic horizon at which it was collected, then its age range would be 3.84 to $3.44 \mathrm{Ma}$ instead of $>3.84 \mathrm{Ma}$ (Fig. 2).

The Mammut-bearing sand-silt-clay outcrop of HAFO locality 042 extends $40 \mathrm{~m}$ eastward along the base of the next major knob of the Sahara complex to HAFO locality 535 (Y, Fig. 2) where additional fragments of mastodon and culated from Hart and Brueseke (1999) using a Fish Canyon sanidine fluence monitor age of 28.201 Ma. The age shown for bed $\mathrm{J}$ is based on the stratigraphic position of bed $\mathrm{J}$ immediately below the $3.44 \pm 0.04$ Ma Deer Gulch lava flow in the northern portion of the monument. The age of the Deer Gulch lava flow is similarly recalculated from Hart and Brueseke (1999)

other faunal elements have eroded out. In 2019, dry screening of sediments at HAFO locality 535 produced a canid tarsal IV (cuboid) (HAFO 26531) and an exploded canine (HAFO 26532, not described). Similar elevation, lithology, and additional surface occurrences of $M$. americanum support HAFO localities 042 and 535 as a synchronous depositional event. Canid material is relatively rare at Hagerman. The presence of additional canid material, from a deposit synchronous with that from where the coordinates placed HAFO 21175, strongly implies that the material belongs to a single canid. The distribution across $40 \mathrm{~m}$ can be explained as landscape scatter by various taphonomic agents prior to burial such as a scavenger removing the hind limb and transporting it away from the carcass (Hill 1979; Behrensmeyer 1983).

\section{Site Geochronology}

A monument-wide tephrostratigraphic study by the U.S. Geological Survey (USGS)-National Park Service (NPS) 


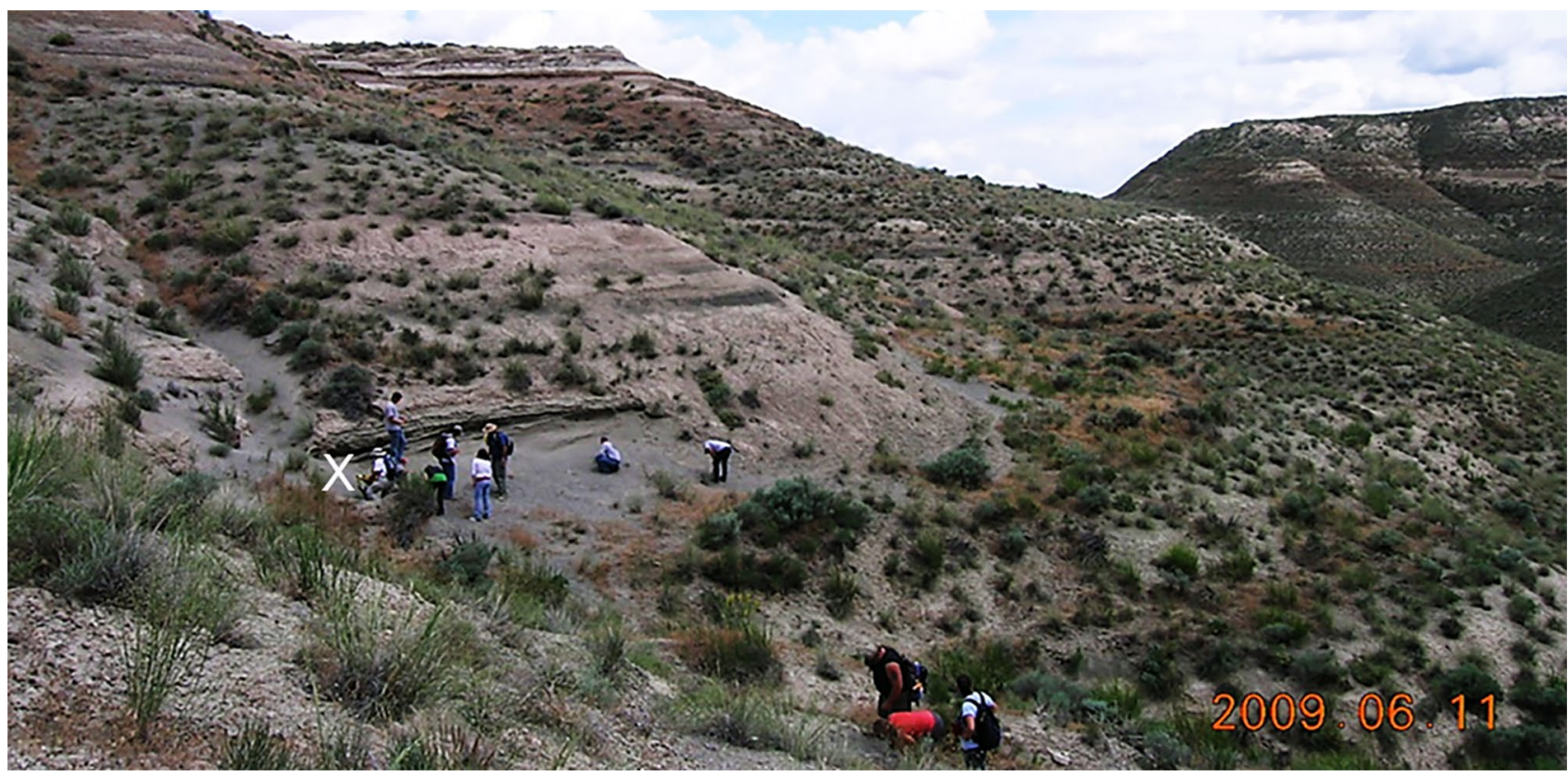

Fig. 3 The base of the Sahara complex on the day the canid dentary (HAFO 21175) was collected. Note the base of the wash to the left, where the only set of coordinates (X) used for this and other specimens collected that day was taken

Hagerman Paleontology, Environments, and Tephrochronology (PET) Project is expanding on previous work by early researchers at Hagerman (Malde and Powers 1962; Malde 1972; Neville et al. 1979; Hart and Brueseke 1999) and has mapped and characterized several volcanic tephra layers in and adjacent to the Sahara complex (Fig. 2). The location where these canid specimens were collected is approximately $25 \mathrm{~m}$ stratigraphically below the $3.84 \pm 0.05 \mathrm{Ma}$ bed $\mathrm{G}$. We have further mapped and geochemically correlated bed $\mathrm{F}$, another basaltic tephra, to approximately five meters stratigraphically below HAFO localities 042 and 535. The age of bed F is estimated at ca. 3.9 Ma based on previous paleomagnetic studies (Neville et al. 1979, updated to GPTS calibration of Ogg 2012). Thus, an early Blancan age of ca. 3.9 Ma is interpolated HAFO localities 042 and 535 and, therefore, HAFO 21175, HAFO 26531, and HAFO 26532.

At another monument locality, an isolated lower molar (HAFO 23808) occurs higher up in the sequence, approximately $17 \mathrm{~m}$ above bed $\mathrm{G}$ at that location. An age of ca. 3.6 Ma is extrapolated for this stratigraphic interval. These data support an estimated age range of approximately 3.9 to 3.6 Ma for this larger canid at Hagerman.

\section{Institutional Abbreviations}

CWT, Christian Collection, West Texas A\&M University, Canyon; F:AMNH, Frick Collections, American Museum of Natural History; HAFO, Hagerman Fossil Beds National Monument; IMNH, Idaho Museum of Natural
History; KU, Kansas University Natural History Museum; LACM, Natural History Museum of Los Angeles County; UMMP, University of Michigan Museum of Paleontology; UNSM, University of Nebraska State Museum; USNM, United States National Museum of Natural History, Smithsonian Institution; WTUC, Panhandle Plains Museum.

\section{Materials and Methods}

\section{Excavation Techniques}

The slopes above and adjacent to HAFO locality 042 were scraped clean of overburden where possible and matrix sediments were screened with a hand-held $3.2 \mathrm{~mm}$ mesh sieve to determine whether those strata contained any fossil material that could have eroded out and been transported downslope to the elevation of HAFO locality 042 . Sediments were also screened from several small excavation pits dug in the blocky clay and silty clay units immediately above the sandsilt-clay backwall of HAFO locality 042 , along the southern face of the upper Sahara blowout, and at HAFO localities 042 and 535. The covered intervals between the lower exposures and the paper shales (Fig. 2) were not screened as the heavy vegetation likely prevents any fossils potentially present in those layers from eroding out to the surface. 


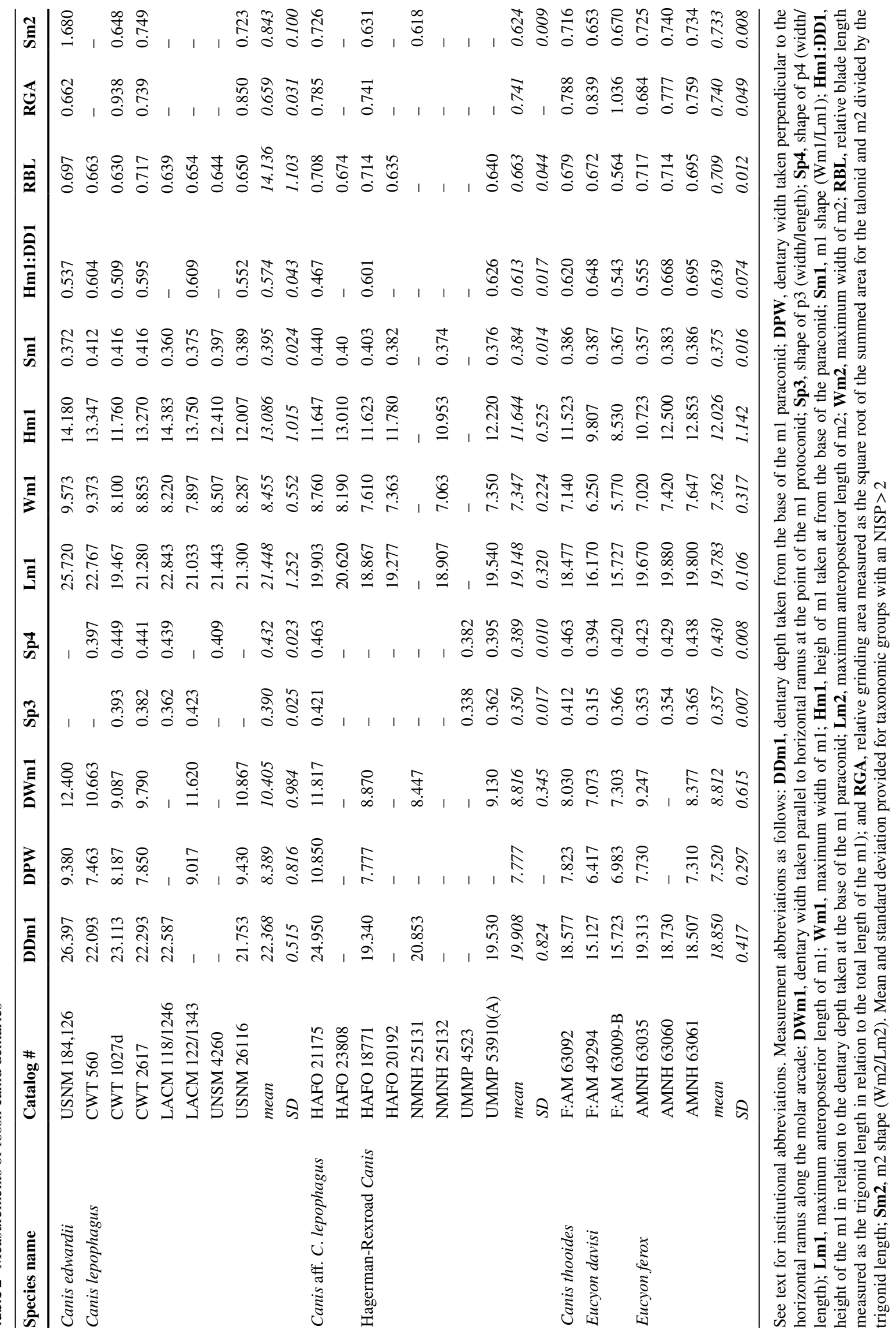




\section{Tephrochronology}

Tephra deposits throughout the monument were mapped, described, and sampled. Samples were then laboratory processed, petrographically characterized, and analyzed for major and minor elemental concentrations via electron microprobe (EMP) and then geochemically correlated utilizing standard tephrochronology methods (Sarna-Wojcicki 1976, 2000; Westgate and Gorton 1981; Sarna-Wojcicki and Davis 1991; Lowe 2011). An initial tephrochronological framework was developed and progressively refined using supplementary field mapping data collected over several years. Volcanic glass compositions acquired by EMP analysis provided geochronologic constraints by geochemically correlating our new samples to previously identified samples in the USGS Tephrochronology Project's reference databases and to published analytical results of tephra samples collected and analyzed by Hart and Brueseke (1999) and Malde and Powers (1962). All tephra names are informal and were established by Malde and Powers (1962) and subsequent authors, except for bed F2 and the basilisk ash layer, both of which were identified for the first time by the USGS-NPS PET Project. These tephra layers are also informally named in keeping with the historic nomenclature put forth by Malde and Powers (1962).

Dates of tephra layers were recalculated from the ${ }^{40} \mathrm{Ar} /{ }^{39} \mathrm{Ar}$ data first reported by Hart and Brueseke (1999) relative to the astronomically tuned Fish Canyon sanidine (FCs) age of 28.201 Ma (Kuiper et al. 2008 using decay constants of Min et al. 2000) and are quoted with a 2-sigma error, although the original dates were reported with a 1-sigma error (written communication, WK Hart). Bed G was directly dated via ${ }^{40} \mathrm{Ar} /{ }^{39} \mathrm{Ar}$ methods $(3.84 \pm 0.05 \mathrm{Ma}$ recalculated, Hart and Brueseke 1999). The estimated age of bed $\mathrm{J}$ is based on its occurrence immediately below the $3.44 \pm 0.04 \mathrm{Ma}$ Deer Gulch lava flow in the northern portion of the monument. Therefore, the inferred age of bed $\mathrm{J}$ is $\geq 3.44 \pm 0.04 \mathrm{Ma}$ (Hart and Brueseke 1999). Paleomagnetism data support an age of ca. 3.9 Ma for bed F based on its position elsewhere in the monument where it lies approximately $120 \mathrm{~m}$ stratigraphically above sediments that preserve the Cochiti Reversed-Polarity Subchron of the Gilbert
Fig. 4 Canis aff. C. lepophagus dentary and $\mathrm{m} 1$ from Hagerman Fossil Beds National Monument. Left partial dentary (HAFO 21175) shown in

a. buccal, b. lingual, and c. occlusal view; right $\mathrm{m} 1$ (HAFO 21808) in d. buccal, e. lingual, and f. occlusal view. Abbreviations as follows: pcp, principal cusp; poc, posterior cusp; cing, posterior cingulum; par, paraconid; pro, protoconid; met, metaconid; ent, entoconid; hyp, hypoconid; crist, transverse cristid. Scale bars equal $10 \mathrm{~mm}$
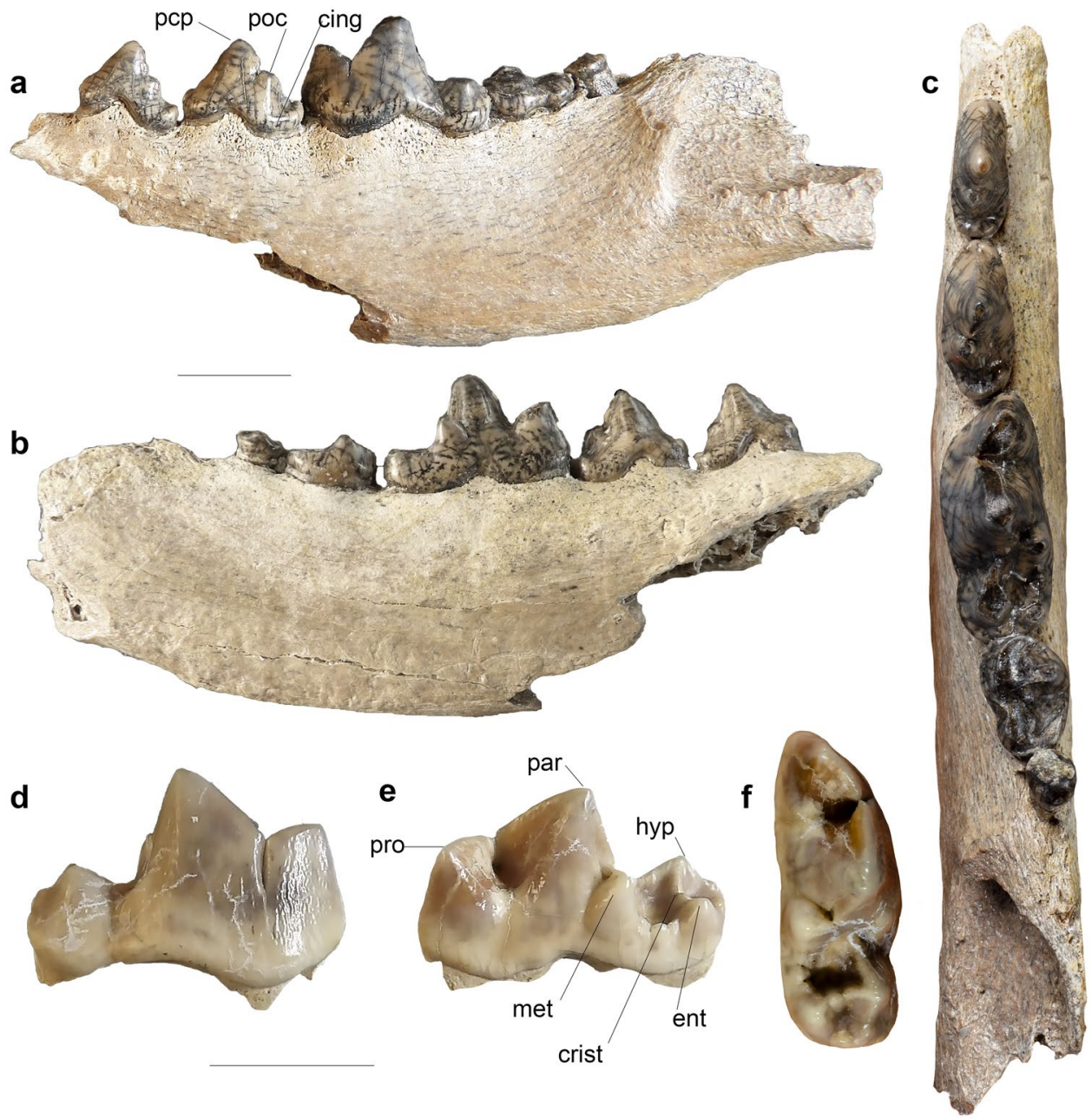
Fig. 5 Canis aff. C. lepophagus left tarsal IV (HAFO 26531).

Specimen shown in a. lateral; b. medial, c. distal, and d. anterior view. Abbreviations as follows: cal, calcaneal facet; cun, cuneiform facet; nav, navicular facet; ten, tendineal sulcus and groove for tendon of fibularis; tub, plantar tuberance; IV, facet for digit IV; $\mathbf{V}$, facet for digit $\mathrm{V}$. Scale bar equals $10 \mathrm{~mm}$
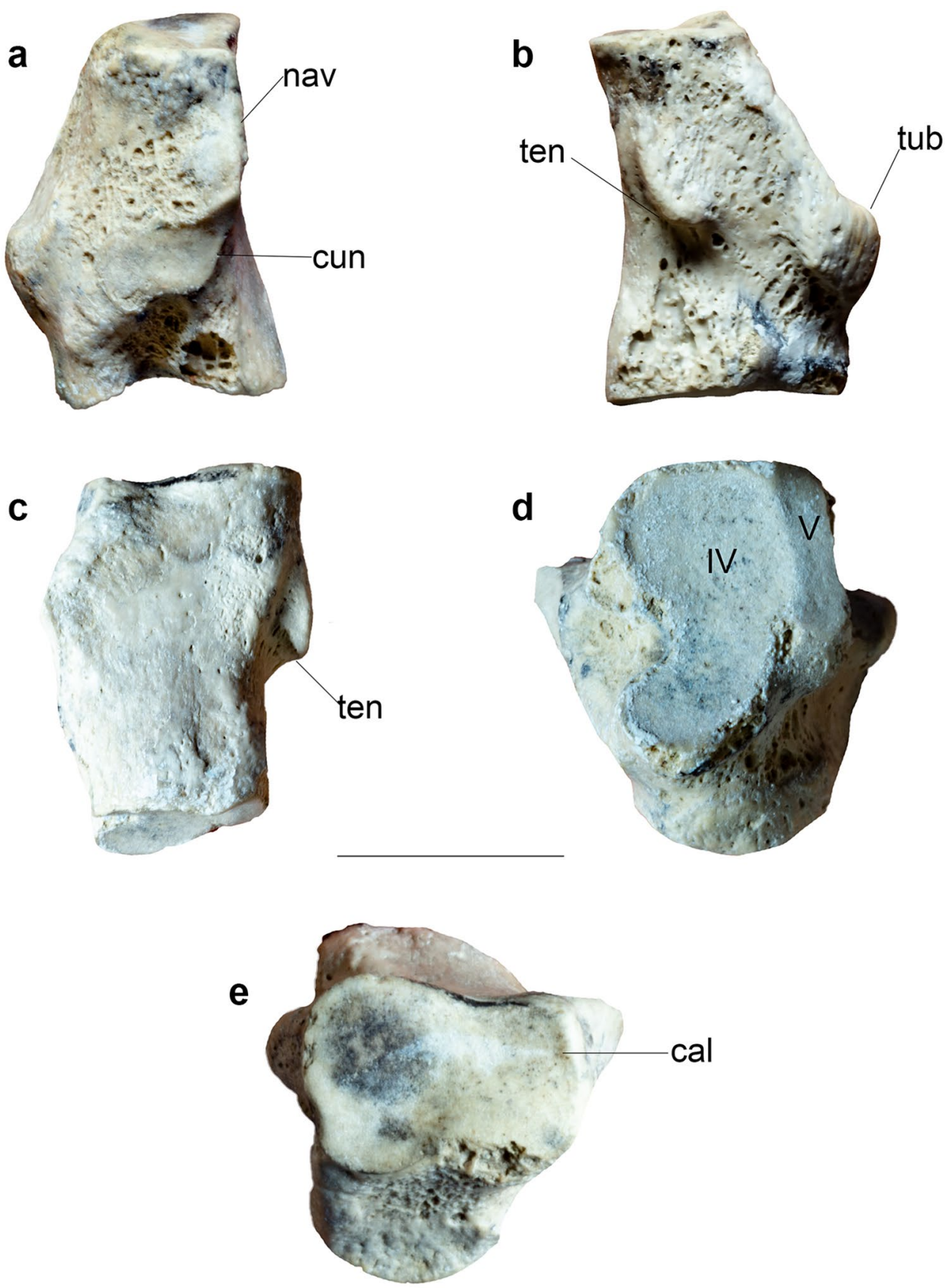

Normal-Polarity Chron (C3n.1n, 4.300-4.187 Ma, updated to GPTS calibration of Ogg 2012) (Neville et al. 1979; Hart and Brueseke 1999).

\section{Dental Nomenclature and Measurements}

See Online Resource 1 for the list of comparative materials. Dental nomenclature follows Tedford et al. (2009). Measurements (Table 2) follow Van Valkenburgh and Wayne (1994) and Tedford et al. (2009). Measurements were acquired using an electronic digital caliper (accuracy to $0.01 \mathrm{~mm}$ ) with serial data output capacity and rounded to the nearest
$0.01 \mathrm{~mm}$. Each measurement was repeated three times with the mean used for each specimen.

Abbreviations are as follows: DDm1, dentary depth taken from the base of the $\mathrm{m} 1$ paraconid; DPW, dentary width taken perpendicular to the horizontal ramus along the molar arcade; DWm1, dentary width taken parallel to the horizontal ramus at the point of the $\mathrm{m} 1$ protoconid; $\mathbf{S p 3}$, shape of p3 (width/length); Sp4, shape of p4 (width/length); Lm1, maximum anteroposterior length of $\mathrm{m} 1 ; \mathbf{W m 1}$, maximum width of $\mathrm{m} 1 ; \mathbf{H m} \mathbf{1}$, height of $\mathrm{m} 1$ taken from the base of the paraconid; Sm1, m1 shape (Wm1/Lm1); Hm1:DD1, height of the $\mathrm{m} 1$ in relation to the dentary depth taken at the base 
of the $\mathrm{m} 1$ paraconid; $\mathbf{L m} \mathbf{2}$, maximum anteroposterior length of $\mathrm{m} 2$; Wm2, maximum width of $\mathrm{m} 2$; RBL, relative blade length measured as the trigonid length in relation to the total length of the m1; RGA, relative grinding area measured as the square root of the summed area for the talonid and $\mathrm{m} 2$ divided by the trigonid length; and $\mathbf{S m} \mathbf{2}, \mathrm{m} 2$ shape (Wm2/ Lm2).

\section{Statistical Analyses}

Summary statistics were conducted using Microsoft Excel. Multivariate statistics were performed using the PAST 4.03 statistical program (Hammer et al. 2001) using data modified from Table 2. Taxa were separated into seven groups (Hagerman-Rexroad Canis, Canis lepophagus, Canis aff. C. lepophagus, Canis edwardii, Canis thooides, Eucyon davisi, and Eucyon ferox).

We used a variance-covariance matrix that disregards groups in Principal Component Analysis (PCA) to maximize variance across groups. We did not standardize data because it was commensurable. Substitution of mean (mean imputation) was used to address missing data when measurements for a given variable were available for at least $50 \%$ of a given group. Estimating missing data by substitution of mean can lead to a decrease in variance and correlativity but does not affect the overall species grouping patterns in small sample sets (Strauss et al. 2003). A lack of suitable measurements across groups led to the removal of RGA, Sm2, SP3, and SP4 from further analysis. Preliminary test runs found the loadings for those measurements had little effect on the PCA. Four PCA analyses were conducted: all taxonomic groups, larger canids, smaller canids, and for the $\mathrm{m} 1$ to allow for inclusion of HAFO 23808. Principle component eigenvalues greater than 1.0 and character loading values of 0.5 or greater are considered. We did not perform a MANOVA due to the small sample sizes.

\section{Systematic Paleontology}

Class MAMMALIA Linnaeus 1758

Order CARNIVORA Bowdich 1821

Family CANIDAE Fischer de Waldheim 1817

Subfamily CANINAE Fischer de Waldheim 1817

Canis Linnaeus 1758

Canis lepophagus Johnston 1938

Canis aff. C. lepophagus (Figs. 4 and 5).

Holotype locality Late Blancan, WTUC 881, North Cita Canyon, stratum no. 2, Ogallala Group, Randall County, Texas (Johnston 1938).

Updated distribution Early Blancan of southern Nevada; early Blancan of southern Idaho; late early
Blancan of Nebraska; late Blancan of Arizona, California, Florida, Idaho, Kansas, Nebraska, New Mexico, and northwestern Mexico (Tedford et al. 2009).

Referred specimens Left partial dentary, HAFO 21175 (HAFO locality $042,919 \mathrm{~m}$ a.s.1., $42.78^{\circ} \mathrm{N}, 114.95^{\circ} \mathrm{W}$ ); right m1, HAFO 23808 (unnamed locality, 957 m a.s.l., $42.80^{\circ} \mathrm{N}, 114.94^{\circ} \mathrm{W}$ ), left tarsal IV (cuboid), HAFO 26531 (HAFO locality 535, 919 m a.s.1., $42.78^{\circ} \mathrm{N}, 114.95$ $\left.{ }^{\circ} \mathrm{W}\right)$.

Site locality Hagerman Fossil Beds National Monument, Twin Falls County, Idaho. Fossil location coordinates are protected by federal law (Paleontological Resource Protection Act, 16 U.S.C. 470aaa-aaa-11). Exact location information will be shared with qualified researchers on request through the NPS Research Permit and Reporting System.

Formation Glenns Ferry Formation (Malde and Powers 1962).

Age Geological age range of specimens approximately 3.9-3.6 Ma, Early Blancan North American Land Mammal Age.

Repository Hagerman Fossil Beds National Monument, NPS, Hagerman, Idaho USA.

Diagnosis HAFO 21175 (Fig. 4a-c) is a left dentary broken anterior to the $\mathrm{p} 3$ with $\mathrm{p} 3-\mathrm{m} 3$ intact and the base of the masseteric fossa preserved. Wear is mild on the p3-4 and $\mathrm{m} 1$ trigonid such that no features are lost and the maximum heights of cuspulids and conids are measurable. Wear is moderate on the $\mathrm{m} 1$ talonid and $\mathrm{m} 2$, and moderately heavy on the $\mathrm{m} 3$ leaving the margins of some features difficult to distinguish. This coyote-sized canid is confidently assigned to Canis and further referred to Canis aff. C. lepophagus based on the following morphological traits assigned to $C$. lepophagus by Tedford et al. (2009): deep masseteric fossa flanked by a strong anterior margin and thick masseteric line; relatively deep horizontal ramus; robust, posteriorly expanded premolars with large, bulbous principle accessory cuspulids and a small secondary accessory cuspulid; $\mathrm{p} 4$ crown superior to $\mathrm{m} 1$ paraconid; robust $\mathrm{m} 1$; entoconulid connecting the metaconid and entoconid; hypoconid and entoconid worn but connected by a weak transverse cristid with the hypoconid broader and the entoconid slightly displaced posteriorly; small hypoconulid presented as a second basin in the talonid; notable anterior expansion of the $\mathrm{m} 2$; retention of two trigonid cusps (metaconid and protoconid); $\mathrm{m} 2$ expanded anteriorly and narrows posteriorly; $\mathrm{m} 3$ ovoid. 


\section{Description}

\section{HAFO 21175}

The mandibular corpus is deep and wide through to the masseteric fossa and exceeds measurements, particularly below and posterior to the carnassial (DDm1, DPW, and DWm1, Table 2), of the largest specimens of Canis lepophagus. The masseteric fossa is shallow and flanked by robust anterior and ventral margins. Tedford et al. (2009) note two mental foramina below the $\mathrm{p} 1-\mathrm{p} 2$ diastema in $C$. lepophagus; the ramus of HAFO 21175 is broken anterior to the $\mathrm{p} 3$ but it lacks the foramen ventral to the $\mathrm{p} 3$ that is seen in Eucyon. The premolars are uncrowded with slight diastemata following the $\mathrm{p} 2, \mathrm{p} 3$, and $\mathrm{p} 4$, as are observed in most specimens of C. lepophagus. Eucyon davisi, E. ferox, and Hagerman/Rexroad Canis exhibit notable diastemata posterior to the $\mathrm{p} 1-\mathrm{p} 3$, but not between the $\mathrm{p} 4-\mathrm{m} 1$. Tooth crowding can vary intraspecifically (Ameen et al. 2017) and may not be a reliable diagnostic trait.

HAFO 21175 has bulbous and posteriorly expanded premolars (Sp3 and Sp4, Table 2) as in Canis arnensis (Lucenti and Rook 2016) that differ from the elongate and bilaterally tapered premolars of E. davisi, E. ferox, Hagerman-Rexroad Canis, and C. lepophagus. The only other early Blancan specimen of C. lepophagus (F:AM 49295) lacks mandibular material for comparison, but upper premolars of F:AM 49295 are elongate as seen in other specimens of C. lepophagus (fig. 41 in Tedford et al. 2009). In Canis thooides, the premolars are also robust, but less elongate and taper posteriorly, while in Canis edwardii the $\mathrm{p} 4$ is reduced relative to the $\mathrm{m} 1$ paraconid.

The principal cusp of the $\mathrm{p} 4$ extends just above the $\mathrm{m} 1$ paraconid and is labially expanded but posteriorly constrained. The p4 primary accessory cuspulid is worn but lobed and more offset labially compared to the accessory cuspulid of the p3. In Eucyon, including E. ferox, a large secondary accessory cuspulid is distinct from the cingulid (Lucenti and Rook 2020). An ancestral trait, the secondary accessory cuspulid is typically lost in later Canis, usually with the primary accessory cuspulid projecting posteriorly to meet an enlarged cingulid ridge, but it is retained in some later taxa, including Canis (Xenocyon) lycaonoides and some specimens of Canis lupus (Tedford et al. 2009) and Canis anthus (USNM 476034). We found the secondary accessory cuspulid in E. davisi (F:AM 49294 and F:AM 63009B) and E. ferox (F:AM 63035, 63060, and 63061) confirms as observed by Lucenti and Rook (2020). In Hagerman-Rexroad Canis and C. edwar$d i i$, a greatly reduced and trenchant secondary accessory cuspulid emerges from the base separate from the posterior accessory cuspulid. It is typically reduced in early
C. lepophagus (see also Tedford et al. 2009), and in a few specimens (CWT 2617 and LACM 1246) the primary accessory cuspulid extends posteriorly to the cingulid such that the secondary accessory cuspulid is lost. In HAFO 21175, C. thooides (F:AM 63092), and Canis aureus thai (USNM 236632) the secondary accessory cuspulid is reduced but retains prominence and emerges off the medial edge of the primary accessory cusp. Canis arnensis also exhibits two distinct accessory cuspulids (Lucenti and Rook 2016).

The $\mathrm{m} 1$ is short in length and height relative to dentary depth compared to most specimens of $C$. lepophagus but with greater breadth expansion across the protoconid creating a broad carnassial (Wm1, Hm1:DD1, and $\mathrm{Sm} 1$, Table 2). Much of this length is attributed to the trigonid, with a moderately trenchant talonid basin. In $C$. lepophagus the $\mathrm{m} 1$ paraconid's anterior face is typically nearly vertical, but it can also present itself as slightly oblique as seen in WTUC 560 (fig. 42 e in Tedford et al. 2009), LACM 1343, USNM 26116, and in HAFO 21175. The metaconid and entoconid are connected by an entoconulid. Severe wear along the labial side of the talonid prevents confirmation of similar cristids between the hypoconid and protoconid. The hypoconid and entoconid are worn, but the wear facet for the hypoconid is twice that of the entoconid with the latter displaced more posterior. Small cristids occur along the cingulid, just posterior to the hypoconid and entoconid, but the cingulid itself is poorly developed. These cristids produce a posteriorly opened hypoconulid shelf that is mesially constrained and separated from the talonid basin by a weak transverse crest. This crest is used by Tedford et al. (2009) to distinguish $C$. lepophagus from the more primitive Eucyon (and Hagerman-Rexroad Canis) where the talonid basin lies open and continuous with the hypoconulid shelf (see also Lucenti and Rook 2020). In Hagerman-Rexroad Canis the hypoconid and entoconid merge, separating the hypoconulid shelf from the talonid basin, as seen in later canids. It is deeper and more triangular but also open due to a poorly defined cingulid ridge, compared to HAFO 21175.

The $\mathrm{m} 2$ is sub-ovoid in occlusal view with expansion across the protoconid and metaconid, labial contraction just posterior to the protoconid, and expansion across the hypoconid and entoconid reduced only relative to the trigonid. The $\mathrm{m} 2$ exhibits heavy, uneven wear with the protoconid worn to the incipient anterolabial cingulid. The metaconid is also worn and only slightly offset posterior to where the protoconid is presumed to have been pre-wear.

The $\mathrm{m} 3$ is ovoid with slight posterior constriction and is heavily worn anteriorly with an unworn hypoconulid shelf. 
a

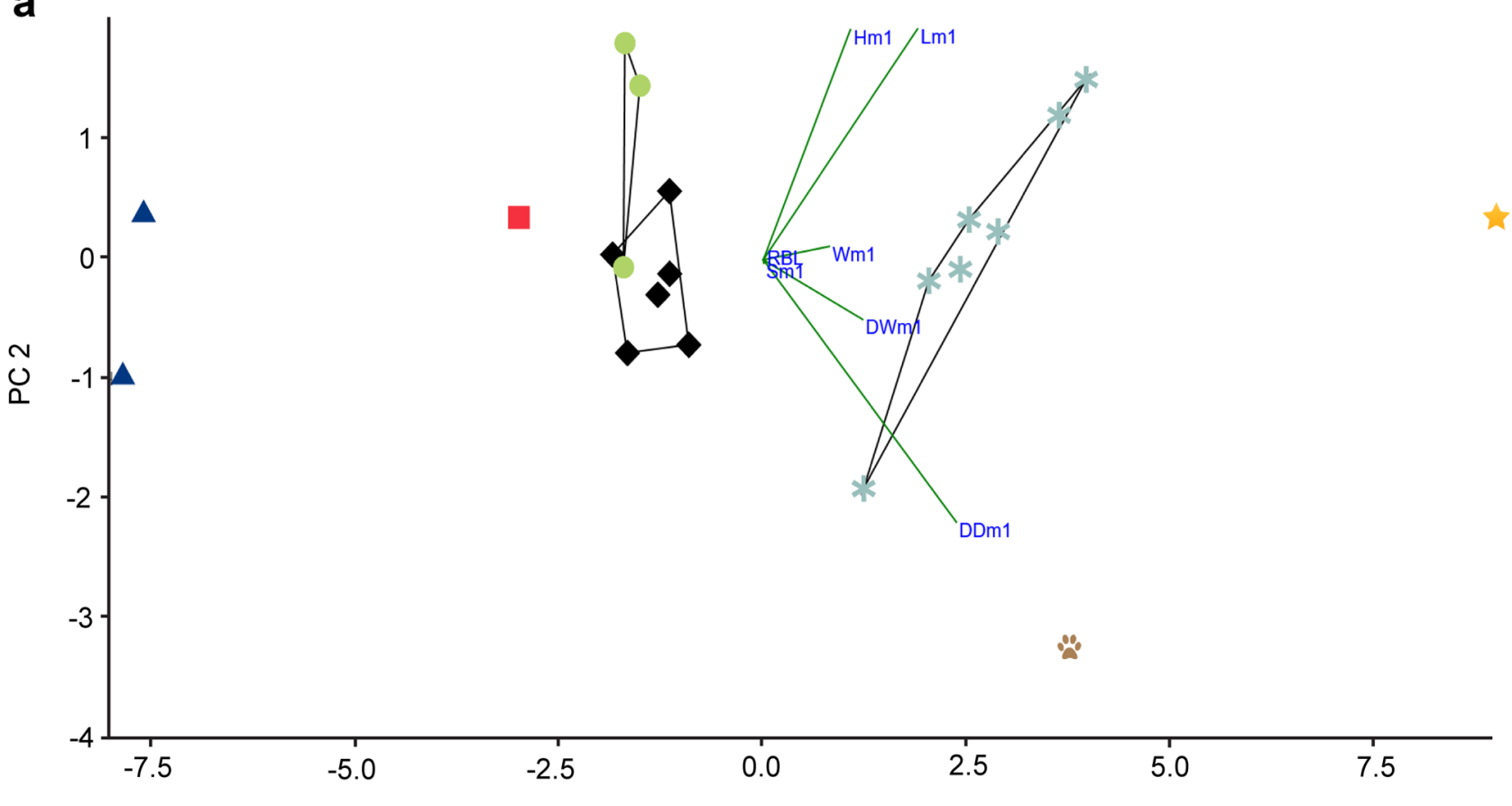

PC 1

b

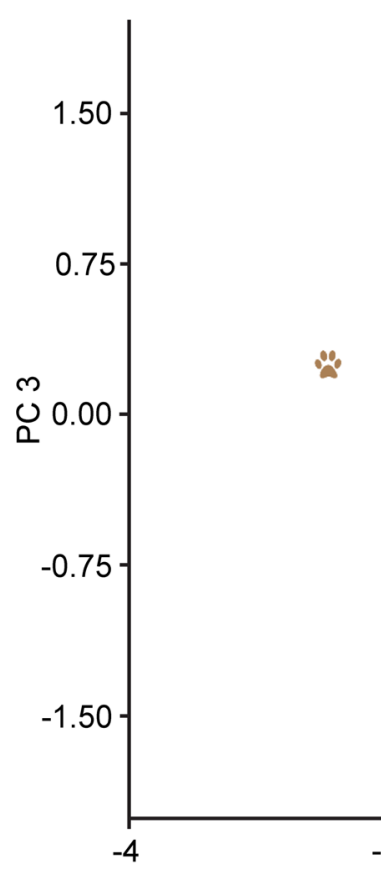

* Canis edwardii

* Canis lepophagus

Canis aff. C. lepophagus

- H-R Canis

- Canis thooides

- Eucyon davisi

- Eucyon ferox
Fig. 6 Principal Component Analysis of all canid groups. a. principal components PC1 vs. PC2 and b. principal components PC2 vs. PC3. HAFO 23808 was not included here due to a lack of suitable meas- urements. Abbreviation: H-R Canis, Hagerman-Rexroad Canis. See Table 3 for summary and loadings 


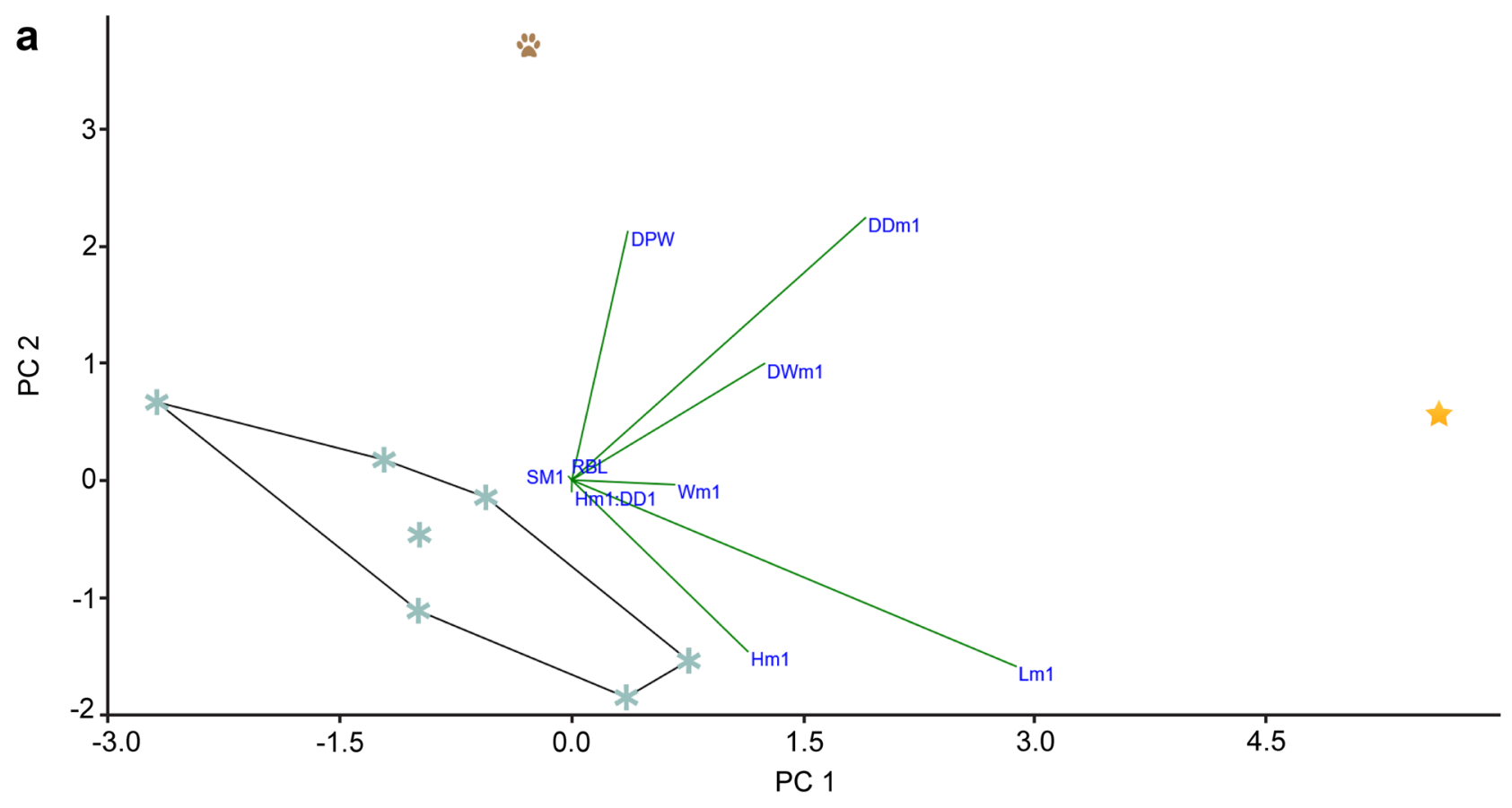

b

* Canis edwardii

* Canis lepophagus

Canis aff. C. lepophagus

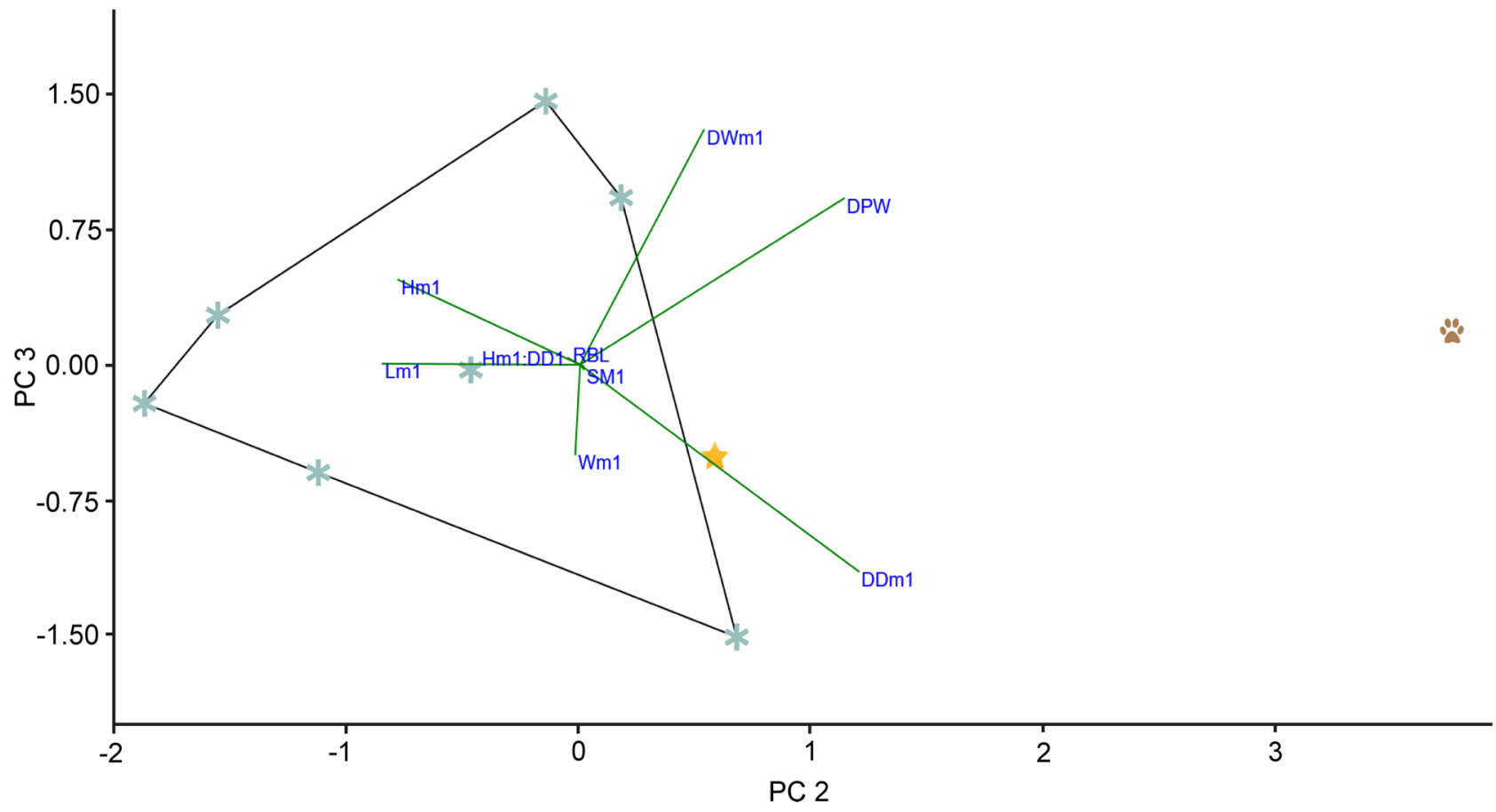

Fig. 7 Principal Component Analysis of large canids. a. principal components PC1 vs. PC2 and b. principal components PC2 vs. PC3. HAFO 23808 was not included here due to a lack of suitable measurements. See Table 4 for summary and loadings 


\section{HAFO 23808}

HAFO 23808 (Fig. 4d-f) is an unworn, isolated right $\mathrm{m} 1$. The specimen aligns with C. lepophagus and not Eucyon or Hagerman-Rexroad Canis based on the following: low series of cristids connects the metaconid and entoconid and the protoconid and hypoconid; strong transverse crest connects the hypoconid and entoconid, closing the talonid basin posterior-labially; entoconid lies posterior to the hypoconid; hypoconulid shelf with a small cusp creates a second distinct basin to the talonid; anterior face of paraconid semi-oblique.

Unlike HAFO 21175, the transverse crest is a distinct series of cristids with a blade-like edge to both the anterior and posterior labial edge of the protoconid. The molar length is shorter than seen in C. lepophagus, but other molar tooth measurements (Wm1, Hm1, and Sm1, Table 2) align it with C. lepophagus. It differs from HAFO 21175 in being longer, taller, and narrower.

\section{HAFO 26531}

HAFO 26531 (Fig. 5) is a left tarsal IV (cuboid) assigned to Canis based on comparison to modern Canis latrans. It falls within the size range of $C$. latrans but is more gracile. The navicular facet is poorly preserved, but the cuneiform facet extends further antero-laterally than in C. latrans (Fig. 5a). On the plantar face, a shortened neck and greatly reduced plantar tuberosity produce an almost shear face in lateral view (Fig. 5b). This differs from the long neck, bulbous tuberosity, and gradual slope in C. latrans. In dorsal view, the anterior face is of approximate width, but the tendineal sulcus is reduced (Fig. 5c). The anterior facet for digit $\mathrm{V}$ is slightly damaged but appears planar while the anterior facet for digit IV is concave and narrows ventrally, as in $C$. latrans, but with a stronger medial curve (Fig. 5d). Anteriorly, the calcaneal facet is narrower and more rectangular than squared (Fig. 5e). There was no tarsal IV specimen of C. lepophagus for comparison, but its Canis-like attributes and physical location within nearby geologically contemporaneous sediments, relative to HAFO 21175, leaves us confident that it belongs to the same individual as HAFO 21175.

\section{Statistical Analysis (Fig. 6-9, Tables 3-6)}

Principal Component Analysis results are provided for all canids (Fig. 6), larger canids (Fig. 7), smaller canids (Fig. 8), and for the m1 only (Fig. 9). Tables 3, 4, 5 and 6 provides loadings for each respective PCA with the eigenvalues and percent variance explained by the major principal components (PC 1, PC 2, and PC 3). Each analysis produced a PC 1 eigen value significantly greater than 1.0 with a variance greater than $85 \%$ apart from the larger canids (Fig. 7 and Table 4) which exhibit lower variance $(57.35 \%)$ in PC 1 with PC 2 contributing notably (29.24\%). In all analyses, HAFO 21175 is morphologically distinct with its separation from other groups driven by its robust dentary (DDm1, DPW, and DWm1, Figs. 6 and 7) and shorter, wider m1 (Fig. 9). Hagerman-Rexroad Canis and Eucyon ferox plot closer to one another than either does to Eucyon davisi (Figs. 6, 8 and 9). HAFO 21175's shorter $\mathrm{m} 1$ lies outside of the C. lepophagus convex hull while HAFO 23808 falls within it due to similarities in the $\mathrm{m} 1$ with that taxon (Fig. 9). Notably, the $\mathrm{m} 1$ exhibits wide variance across $C$. lepophagus.

\section{Taxonomic Assignment}

We assign HAFO 21175 to Canis aff. C. lepophagus but not without acknowledging some notable differences. Features in the lower dentition best align it with C. lepophagus, but the depth and thickness of the mandibular corpus, particularly below and posterior to the carnassial, exceed that of this mostly late Blancan species. The only other earlier Blancan specimen of $C$. lepophagus (F:AM 49295) lacks a preserved dentary for direct comparison, but cranial measurements place that specimen within the range for later C. lepophagus (Tedford et al. 2009). Principal Component Analysis supports the distinctive morphospace of HAFO 21175 compared to other canid groups (Figs. 6, 7, and 9), while HAFO 23808 falls within C. lepophagus (Fig. 9, Tables 2 and 6). Measurements for SP3 and SP4 were not used in the PCA, but their shape further distinguishes HAFO 21175 from C. lepophagus.

Mandibular thickening below the $\mathrm{m} 1$ and $\mathrm{m} 2$ in HAFO 21175 points to greater force and either increased durophagy and/or reliance on larger prey (Van Valkenburgh 1991; Wroe et al. 2005). Wider and rounder premolars also support greater durophagy (Van Valkenburgh 1991; Van Valkenburgh et al. 2004) and further differentiates it from C. lepophagus. Heavy wear along the grinding surface (RGA) may lend additional support for hard part consumption and/or be an indicator of age. The enlarged premolars and reduced grinding area, coupled with a more robust mandibular corpus, could suggest a robust male (Van Valkenburgh and Sacco 2002; Tedford et al. 2009; O'Keefe et al. 2013; Brannick et al. 2015), but HAFO 21175 would still be an anomalously robust jawed, early specimen of $C$. lepophagus. It may instead represent an early branching event, potentially leaving C. lepophagus polyphyletic. Given the limited material and high variability seen in this taxon, the conservative approach is to refer it to $C$. aff. C. lepophagus. HAFO 23808 better aligns with $C$. lepophagus, but as an isolated $\mathrm{m} 1$ is also left as $C$. aff. C. lepophagus. 
Table 3 Loadings from the first three principal components for all canids (Fig. 6) with eigenvalues and percentage of the variance explained by each major principal component

\begin{tabular}{lccc}
\hline & PC 1 & PC 2 & PC 3 \\
\hline DDm1 & $\mathbf{0 . 6 7 0 6 9}$ & $\mathbf{- 0 . 6 2 0 1 9}$ & -0.35107 \\
DWm1 & 0.34478 & -0.14084 & $\mathbf{0 . 7 0 4 8 7}$ \\
Lm1 & $\mathbf{0 . 5 3 5 8 2}$ & $\mathbf{0 . 5 4 6 1 1}$ & 0.31218 \\
Hm1 & 0.30246 & $\mathbf{0 . 5 4 4 2 4}$ & $\mathbf{- 0 . 5 2 7 1 1}$ \\
Eigenvalue & 14.9036 & 1.31533 & 7.7816 \\
\% Variance & 88.17 & 0.345395 & 2.0434 \\
\hline
\end{tabular}

DDm1 dentary depth taken from the base of the $\mathrm{m} 1$ paraconid, DWm1 dentary width taken parallel to the horizontal ramus at the point of the $\mathrm{m} 1$ protoconid, $\mathbf{L m} \mathbf{1}$ maximum anteroposterior length of $\mathrm{m} 1, \mathbf{H m} \mathbf{1}$ height of $\mathrm{m} 1$ taken from the base of the paraconid

Table 4 Loadings from the first three principal components for large canids (Fig. 7) with eigenvalues and percentage of the variance explained by each major principal component

\begin{tabular}{lccc}
\hline & PC 1 & PC 2 & PC 3 \\
\hline DDm1 & $\mathbf{0 . 7 3 4 9 8}$ & -0.40816 & 0.002713 \\
DWm1 & 0.48589 & $\mathbf{0 . 5 7 4 7 3}$ & $\mathbf{- 0 . 5 5 0 9 1}$ \\
Lm1 & 0.09249 & $\mathbf{0 . 5 4 4 2 9}$ & 0.44324 \\
Hm1 & 0.31868 & 0.2552 & $\mathbf{0 . 6 2 5 5}$ \\
Eigenvalue & 5.4253 & 2.76518 & 0.751545 \\
\% Variance & 57.346 & 29.238 & 7.9465 \\
\hline
\end{tabular}

DDm1 dentary depth taken from the base of the $\mathrm{m} 1$ paraconid, DWm1 dentary width taken parallel to the horizontal ramus at the point of the $\mathrm{m} 1$ protoconid, $\mathbf{L m} \mathbf{1}$ maximum anteroposterior length of $\mathrm{m} 1, \mathbf{H m} \mathbf{1}$ height of $\mathrm{m} 1$ taken from the base of the paraconid

Table 5 Loadings from the first three principal components for small canids (Fig. 8) with eigenvalues and percentage of the variance explained by each major principal component

\begin{tabular}{lccc}
\hline & PC 1 & PC 2 & PC 3 \\
\hline DDm1 & $\mathbf{0 . 6 6 3 5 4}$ & $\mathbf{- 0 . 6 6 3 9 9}$ & -0.33133 \\
DWm1 & 0.41654 & $\mathbf{0 . 6 5 9 1 1}$ & -0.44589 \\
Lm1 & $\mathbf{0 . 5 2 8 9 7}$ & 0.29276 & $\mathbf{0 . 5 5 0 8 5}$ \\
Hm1 & 0.24917 & -0.098976 & $\mathbf{0 . 5 9 9 2 2}$ \\
Eigenvalue & 6.10769 & 0.746083 & 0.191706 \\
\% Variance & 86.158 & 10.525 & 2.7043 \\
\hline
\end{tabular}

DDm1 dentary depth taken from the base of the $\mathrm{m} 1$ paraconid, DWm1 dentary width taken parallel to the horizontal ramus at the point of the $\mathrm{m} 1$ protoconid, $\mathbf{L m} \mathbf{1}$ maximum anteroposterior length of $\mathrm{m} 1, \mathbf{H m} 1$ height of $\mathrm{m} 1$ taken from the base of the paraconid
Table 6 Loadings from the first three principal components for the $\mathrm{m} 1$ of all canids (Fig. 9) with eigenvalues and percentage of the variance explained by each major principal component

\begin{tabular}{llcl}
\hline & PC 1 & PC 2 & PC 3 \\
\hline Lm1 & $\mathbf{0 . 8 1 0 2 2}$ & -0.43234 & -0.39531 \\
Hm1 & 0.48894 & $\mathbf{0 . 8 7 0 9}$ & 0.049598 \\
Wm1 & 0.32322 & -0.23368 & $\mathbf{0 . 9 1 5 7 7}$ \\
Sm1 & 0.0008618 & -0.002032 & 0.051392 \\
Eigenvalue & 6.82545 & 0.325229 & 0.1546121 \\
\% Variance & 93.54 & 4.4571 & 2.0025 \\
\hline
\end{tabular}

Lm1 maximum anteroposterior length of $\mathrm{m} 1, \mathbf{H m} \mathbf{1}$ height of $\mathrm{m} 1$ taken from the base of the paraconid, Wm1 maximum width of $\mathrm{m} 1$, Sm1 m1 shape (Wm1/Lm1)

\section{Discussion}

The study of extant canid relationships, particularly among the wolf- and jackal-like canids, incorporates morphological, behavioral, and genetic data, yet our understanding of those canids remains in flux (Nowak and Federof 2002; Schwartz and Vucetich 2009; Rueness et al. 2011; Gaubert et al. 2012; Viranta et al. 2017; Sinding et al. 2018; Waples et al. 2018; Joshi et al. 2020; Stoyanov 2020). Recently diverged sister taxa can overlap substantially morphologically, and species introgression is common today (Fredrickson and Hedrick 2006; Galov et al. 2015; Gopalakrishnan et al. 2018) and likely in the past. Allometric and phenotypic plasticity in extant canids (Machado and Teta 2020), particularly of facial traits, can leave larger or younger conspecifics as outliers and potentially lead to misidentification as distinct species (Wayne 1986; Prevosti et al. 2013; Gopalakrishnan et al. 2018; Machado et al. 2018; Chemisquy et al. 2019; Machado and Teta 2020). Environmental stresses, changes to niche space, and other variables can further impact canid selection pressures at the population level (Van Valkenburgh and Wayne 1994; O'Keefe et al. 2013; Brannick et al. 2015; Machado and Teta 2020). This can lead to morphological (Van Valkenburgh and Wayne 1994; Slater et al. 2009; Meachen et al. 2014; Brannick et al. 2015), isotopic (Pilot et al. 2012), or genetic (Nowak and Federoff 2002; Schweizer et al. 2016; Angelici et al. 2019) intraspecific variance across populations, even in geographically overlapping populations (Leonard et al. 2007; O'Keefe 


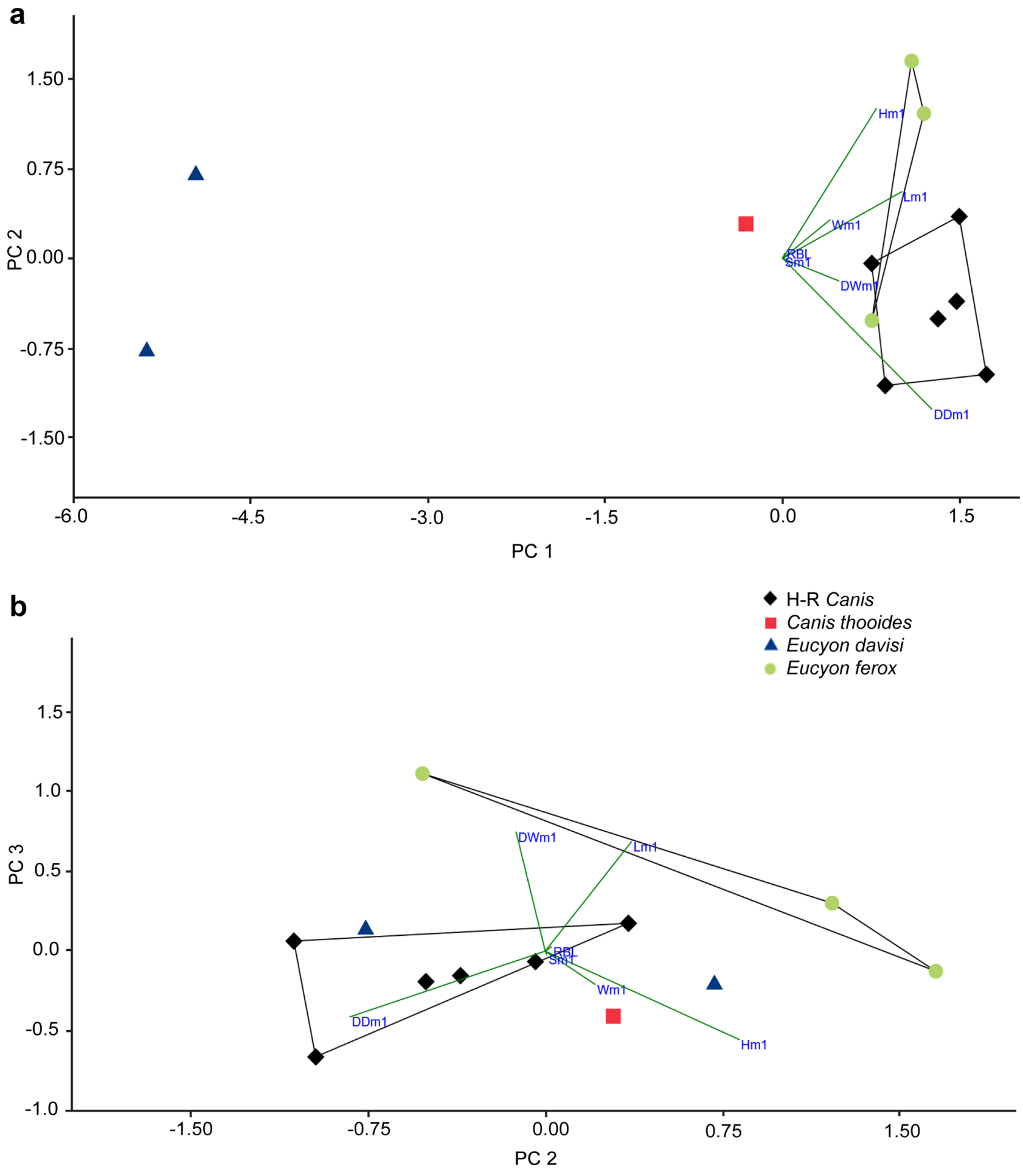

Fig. 8 Principal Component Analysis of small canids. a. principal components PC1 vs. PC2 and b. principal components PC2 vs. PC3. Abbreviation: H-R Canis, Hagerman-Rexroad Canis. See Table 5 for summary and loadings 


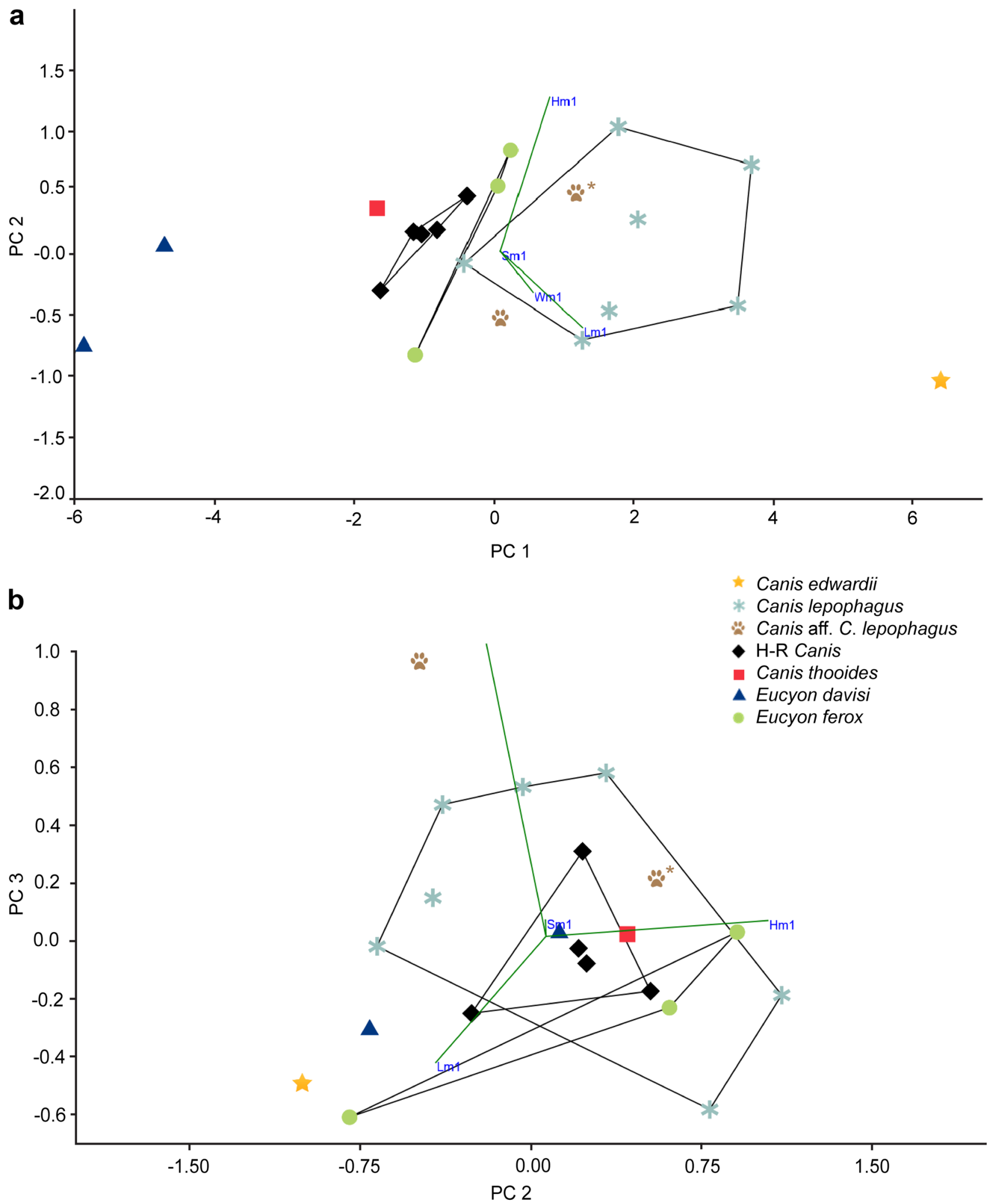

Fig. 9 Principal Component Analysis of the $\mathrm{m} 1$ in all canids. a. principal components PC1 vs. PC2 and b. principal components PC2 vs. PC3. HAFO 23608 (brown paw print) is distinguished from HAFO
21175 by an asterisk. Abbreviation: H-R Canis, Hagerman-Rexroad Canis. See Table 5 for summary and loadings 
et al. 2013; Sansalone et al. 2015; Flower 2016). These factors have led to difficulties in distinguishing extant canid species (Prevosti et al. 2013; von Holdt et al. 2016; Chemisquy et al. 2019).

Not surprisingly, similar issues arise in the study of fossil canid accumulations, but with even fewer types of data to aid us in reconstructing canid relationships. In the late Pleistocene, larger accumulations of canids have revealed clinal shifts in canid body size and morphology (Leonard et al. 2007; Slater et al. 2009; Meachen and Samuels 2012; O'Keefe et al. 2013; Sansalone et al. 2015; Flower 2016) and changes to in-situ populations over time due to changes in climate (Brannick et al. 2015) and competition (Meachen et al. 2014), but even then, phylogenetic relationships remain in flux (Perri et al. 2021). Pre-Pleistocene North American canid samples, such as those from Hagerman, are currently of insufficient size for population variance studies.

The limited material and often-ambiguous morphological traits of Canis leaves the taxonomic status of Hagerman's canids as tentative, with the larger assigned to the group of canids currently referred to Canis lepophagus and a more gracile species known from both Hagerman and Rexroad that is best left, for now, as Canis sp. Whether Canis lepophagus gave rise to the jackal-like lineage of $C$. thooides and, possibly, to $C$. arnensis is also unresolved but possible given some overall similarities in dental traits.

If Canis lepophagus remain monospecific, then this species was widespread across much of what is now the southwestern, central, and northwestern United States, and long-lived with a known range of 4.5 Ma (Panaca Formation, Nevada, Lindsay et al. 2002) to $2.5 \mathrm{Ma}$ (Grandview Fauna, Idaho, Repenning et al. 1995). This same land area today supports several contemporaneous species (and subspecies) of Canis including taxa that are only genetically identifiable as taxonomically distinct (Wilson et al. 2000; Schwartz and Vucetich 2009; Heppenheimer et al. 2018; Machado and Teta 2020).

\section{Conclusion}

Canid systematics is in a state of flux as new discoveries and a broader range of applied techniques continue to change our understanding of extant and extinct canid relationships. For extant canids, the application of genetic, isotopic, and ecological data has deemed some morphologically distinct populations conspecific while other morphologically indistinct populations were found to differ significantly in diet, behavior, and/or genetics, thus leading to taxonomic reassignment. For extinct canids, especially in the North American Pliocene, a mix of synapomorphies and apparent intraspecific variance coupled with small, incomplete sample sizes have led to multiple morphological-based taxonomic reassignments of specimens at both the species and genus level.
The canids at Hagerman Fossil Beds National Monument highlight the ambiguities of canid morphological traits in assigning taxonomic affinity. Hagerman's smaller canid was published as Canis lepophagus, Canis ferox, and most recently relegated to Canis sp., with C. ferox no longer considered a valid taxon. Newly described Hagerman specimens of a larger coyote-sized canid morphologically align best with and are assigned to Canis aff C. lepophagus, but with an unusually robust dentary that adds to the variation already evident in that species. Canis lepophagus spans two million years and much of the continental United States and may represent multiple speciation events or phenotypic variance related to geographic and ecological differences that additional fossil material or the application of new techniques may help to shed light on.

Supplementary Information The online version contains supplementary material available at https://doi.org/10.1007/s10914-021-09591-4.

Acknowledgements We thank William K. Hart, Matthew Brueseke, and Charles Bruce Minturn III for their geochemical and geochronological data, with particular thanks to William K. Hart for his continued guidance and support. We thank Lindsay A. Jurgielewicz, Ruth O'Leary, and Meng Jin (AMNH), Mary Thompson (IMNH), K. Chris Beard and Megan Sims (KU), Samuel McLeod (LACM), Suzanne Peurach and Amanda Millhouse (USNM), Adam Rountrey (UMMP), Ross Secord and George Corner (UNSM), and Mary Moore and Veronica Arias (WTUC) for specimen loans. We thank the USGS Menlo Park Electron Microbeams Facility and the Stanford Mineral and Microchemical Analysis Facility for providing electron microprobe data for tephrochronological correlations. KAP is grateful to Gerald Schultz, Julie Meachen, and David Polly for their correspondence and suggestions and to Phish for getting her through 2020. We are indebted to Elmira Wan, Scott Starratt, Michael Diggles, William K. Hart, Darin Croft, Samantha Hopkins, and an anonymous reviewer for their insight, corrections, and suggestions on making this a better paper.

Author Contributions Both authors contributed to the methodology, validation, formal analysis, investigation, resources, data curation and figures, and reviewed, edited, and approved the final manuscript. Prassack also contributed to the conceptualization, original draft writing, project administration, and funding acquisition.

Funding This research was funded by a three-year U.S. Geological Survey-Natural Resources Preservation Program (USGS-NRPP) research grant in cooperation between the USGS and the National Park Service (NPS). Additional support came from the NPS Pacific Northwest Region, NPS Southern Idaho Parks, and USGS Tephrochronology Project.

Availability of Data and Material A list of modern and fossil specimens considered in this study are found in Online Resource 1. Table 2 provides measurements data for fossil specimens. New fossil specimens described here are housed in on-site collections at Hagerman Fossil Beds National Monument in Idaho. Fossil locality data are protected by federal law (Paleontological Resource Protection Act, 16 U.S.C. 470aaa-aaa-11). Exact location information will be shared with qualified researchers with an appropriate permit which can be obtained through the NPS Research Permit and Reporting System. 


\section{Declarations}

Competing Interests Both authors certify that they have no conflicts of interest to declare with respect to this manuscript. Any use of trade, firm, or product names is for descriptive purposes only and does not imply endorsement by the U.S. Government.

Open Access This article is licensed under a Creative Commons Attribution 4.0 International License, which permits use, sharing, adaptation, distribution and reproduction in any medium or format, as long as you give appropriate credit to the original author(s) and the source, provide a link to the Creative Commons licence, and indicate if changes were made. The images or other third party material in this article are included in the article's Creative Commons licence, unless indicated otherwise in a credit line to the material. If material is not included in the article's Creative Commons licence and your intended use is not permitted by statutory regulation or exceeds the permitted use, you will need to obtain permission directly from the copyright holder. To view a copy of this licence, visit http://creativecommons.org/licenses/by/4.0/.

\section{References}

Ameen C, Hulme-Beaman A, Evin A, Germonpré M, Britton K, Cucchi T, Larson G, Dobney K (2017) A landmark-based approach for assessing the reliability of mandibular tooth crowding as a marker of dog domestication. J Archaeol Sci 85:41-50. https:// doi.org/10.1016/j.jas.2017.06.014

Anderson E (1984) Review of the small carnivores of North America during the last 3.5 million years. In: Genoways HH, Dawson MR (eds) Contributions in Quaternary Vertebrate Paleontology No. 8, Carnegie Museum of Natural History, pp 257-266. https://doi. org/10.5962/bhl.title.123727

Angelici FM, Ciucani MM, Angelini S, Annesi F, Caniglia R, Castiglia R, Fabbri E, Galaverni M, Palumbo D, Ravegnini G, Rossi L (2019) The Sicilian wolf: genetic identity of a recently extinct insular population. Zool Sci 36(3):189-197. https://doi.org/10. 2108/zs180180

Behrensmeyer KA (1983) Patterns of natural bone distribution on recent land surfaces: Implications for archaeological site formation. In: Clutton-Brock J, Grigson C (eds) Animals and Archaeology, Vol. I, Hunters and Their Prey, British Archaeological Reports International Series I63, pp 93-106

Bell CJ, Lundelius Jr EL, Barnosky AD, Graham RW, Lindsay EH, Ruez Jr DR, Semken Jr HA, Webb SD, Zakrzewski RJ (2004) The Blancan, Irvingtonian, and Rancholabrean mammal ages. In: Woodburne MO (ed) Late Cretaceous and Cenozoic Mammals of North America: Biostratigraphy and Geochronology. Columbia University Press, New York, pp 232-314. https://doi.org/10. 7312/wood13040-009

Bever GS (2005) Morphometric variation in the cranium, mandible, and dentition of Canis latrans and Canis lepophagus (Carnivora: Canidae) and its implications for the identification of isolated fossil specimens. Southwest Nat 42-56. https://doi.org/ 10.1894/0038-4909(2005)050\%3C0042:MVITCM\%3E2.0.CO;2

Biknevicius AR, Ruff CB (1992) The structure of the mandibular corpus and its relationship to feeding behaviors in extant carnivorans. J Zool 228:479-507. https://doi.org/10.1111/j.14697998.1992.tb04450.x

Bjork PR (1970) The Carnivora of the Hagerman local fauna (late Pliocene) of southwestern Idaho. Philos Trans R Soc B 60:1-54. https://doi.org/10.2307/1006119
Bowdich TE (1821) An analysis of the natural classifications of Mammalia, for the use of students and travelers. Journal Smithsonian Paris

Brannick AL, Meachen JA, O'Keefe FR (2015) Microevolution of jaw shape in the dire wolf, Canis dirus, at Rancho La Brea. Sci Ser Nat Hist Mus Los Angel Cty 42:23-32

Chemisquy MA, Stom JC, Francisco J, Martinez P, Raimondi V, Acosta-Jamett G, Montoya-Burgos J (2019) How many species of grey foxes (Canidae, Carnivora) are there in southern South America? Mastozool Neotrop 26:81-97. https://doi.org/ 10.31687/SAREMMN.19.26.1.0.16

Chetri M, Jhala YV, Jnawali SR, Subedi N, Dhakal M, Yumnam B (2016) Ancient Himalayan wolf (Canis lupus chanco) lineage in Upper Mustang of the Annapurna Conservation Area, Nepal. ZooKeys 582:143. https://doi.org/10.3897/zookeys.582.5966

de Bonis L, Peigné S, Likius A, Mackaye HT, Vignaud P, Brunet M (2007) The oldest African fox (Vulpes riffautae n. sp., Canidae, Carnivora) recovered in late Miocene deposits of the Djurab desert, Chad. Naturwissenschaften 94(7):575. https://doi.org/ 10.1007/s00114-007-0230-6

Fan Z, Silva P, Gronau I, Wang S, Armero AS, Schweizer RM, Ramirez O, Pollinger J, Galaverni M, Del-Vecchy DO, Du L (2016) Worldwide patterns of genomic variation and admixture in gray wolves. Genome Res 26(2):163-173. https://doi.org/10.1101/gr.197517.115

Fischer de Waldheim G (1817) Adversaria zoologica. Mem Soc Nat Mosc 5:357-472

Flower LOH (2016) New body mass estimates of British Pleistocene wolves: Palaeoenvironmental implications and competitive interactions. Quat Sci Rev 149:230-247. https://doi.org/ 10.1016/j.quascirev.2016.07.023

Fredrickson RJ, Hedrick PW (2006) Dynamics of hybridization and introgression in red wolves and coyotes. Conserv Biol 20:1272-1283. https://doi.org/10.1111/j.1523-1739.2006.00401.x

Galov A, Fabbri E, Caniglia R, Arbanasić H, Lapalombella S, Florijančić T, Bošković I, Galaverni M, Randi E (2015) First evidence of hybridization between golden jackal (Canis aureus) and domestic dog (Canis familiaris) as revealed by genetic markers. R Soc Open Sci 2(12):150450. https://doi.org/10.1098/rsos.150450

Gaubert P, Bloch C, Benyacoub S, Abdelhamid A, Pagani P, Djagoun CAMS, Couloux A, Dufour S (2012) Reviving the African wolf Canis lupus lupaster in North and West Africa: a mitochondrial lineage ranging more than $6,000 \mathrm{~km}$ wide. PLoS One 7(8): e42740. https://doi.org/10.1371/journal.pone.0042740

Geraads D (2011) A revision of the fossil Canidae (Mammalia) of north-western Africa. Palaeontol 54(2):429-446. https://doi.org/ 10.1111/j.1475-4983.2011.01039.x

Giles E (1960) Multivariate analysis of Pleistocene and Recent coyotes (Canis latrans) from California. Univ Publ Geol 36, 369390. https://doi.org/10.5962/bhl.title.62036

Gopalakrishnan S, Sinding MHS, Ramos-Madrigal J, Niemann J, Castruita JAS, Vieira FG, Carøe C, de Manuel Montero M, Kuderna L, Serres A, González-Basallote VM (2018) Interspecific gene flow shaped the evolution of the genus Canis. Curr Biol 28(21):3441-3449. https://doi.org/10.1016/j.cub.2018.08.041

Hammer Ø, Harper DAT, Ryan PD (2001) PAST: Paleontological statistics software package for education and data analysis. Palaeontologia Electronica 4(1):9

Hart WK, Brueseke ME (1999) Analysis and dating of volcanic horizons from Hagerman Fossil Beds National Monument and a revised interpretation of eastern Glenns Ferry Formation chronostratigraphy: a report of work accomplished and scientific results. Nat. Park Serv. Rep. 1443A:1-37

Heppenheimer E, Brzeski KE, Wooten R, Waddell W, Rutledge LY, Chamberlain MJ, Stahler DR, Hinton JW, VonHoldt BM (2018) Rediscovery of red wolf ghost alleles in a canid population along the American Gulf Coast. Genes 9(12):618. https://doi.org/10. 3390/genes9120618 
Hibbard CW (1941) New mammals from the Rexroad fauna, upper Pliocene of Kansas. Am. Midl Nat 26:337-368. https://doi.org/ $10.2307 / 2420965$

Hill A (1979) Disarticulation and scattering of mammal skeletons. Paleobiol 5(3):261-274

Johnston CS (1938) Preliminary report on the vertebrate type locality of Cita Canyon, and the description of an ancestral coyote. Am J Sci 35:383-39. https://doi.org/10.2475/ajs.s5-35.209.383

Joshi, B, Lyngdoh S, Singh SK, Sharma R, Kumar V, Tiwari VP, Dar SA, Maheswari A, Pal R, Bashir T, Reshamwala HS (2020) Revisiting the woolly wolf (Canis lupus chanco) phylogeny in Himalaya: Addressing taxonomy, spatial extent, and distribution of an ancient lineage in Asia. PLoS One 15(4): e0231621. https:// doi.org/10.1371/journal.pone.0231621

Kuiper KF, Deino A, Hilgen FJ, Krijgsman W, Renne PR, Wijbrans JR (2008) Synchronizing rock clocks of Earth history. Science 320 (5875):500-504. https://doi.org/10.1126/science.1154339

Kurtén B (1974) A history of coyote-like dogs (Canidae, Mammalia). Acta Zool Fenn 140:1-38

Kurtén B, Anderson E (1980) Pleistocene Mammals of North America. Columbia University Press, New York

Leonard JA, Vilà C, Fox-Dobbs K, Koch PL, Wayne RK, Van Valkenburgh B (2007) Megafaunal extinctions and the disappearance of a specialized wolf ecomorph. Curr Biol 17(13):1146-1150. https://doi.org/10.1016/j.cub.2007.05.072

Lindsay E, Mou YUN, Downs W, Pederson J, Kelly TS, Henry C, Trexler J (2002) Recognition of the Hemphillian/Blancan boundary in Nevada. J Vertebr Paleontol 22(2):429-442. https:// doi.org/10.1671/0272-4634(2002)022[0429:ROTHBB]2.0.CO;2

Linnaeus C (1758) Systema naturae per regna tria naturae, secundum Classes, Ordines, Genera, Species, cum characteribus, differentiis, synonymis, locis. Tomus I. Laurentius Salvius, Stockholm. https://doi.org/10.5962/bhl.title.559

Lowe DJ (2011) Tephrochronology and its application: a review. Quat Geochronol 6(2):107-153. https://doi.org/10.1016/j.quageo.2010.08.003

Lucenti SB, Rook L (2016) A review on the Late Villafranchian medium-sized canid Canis arnensis based on the evidence from Poggio Rosso (Tuscany, Italy). Quat Sci Rev 151:58-71. https:// doi.org/10.1016/j.quascirev.2016.09.005

Lucenti SB, Rook L (2020) “Canis" ferox revisited: diet ecomorphology of some long gone (late Miocene and Pliocene) fossil dogs. J Mamm Evol 28:285-306. https://doi.org/10.1007/s10914-020-09500-1

Machado FA, Teta P (2020) Morphometric analysis of skull shape reveals unprecedented diversity of African Canidae. J Mammal 101(2):349-360. https://doi.org/10.1093/jmammal/gyz21

Machado FA, Zahn TMG, Marroig G (2018) Evolution of morphological integration in the skull of Carnivora (Mammalia): changes in Canidae lead to increased evolutionary potential of facial traits. Evol 72(7):1399-1419. https://doi.org/10.1111/evo.13495

Malde HE (1972) Stratigraphy of the Glenns Ferry Formation from Hammet to Hagerman, Idaho: US Geol Surv Bull 1331-D:1-19. https://doi.org/10.3133/b1331D

Malde HE (1982) The Yahoo Clay: A lacustrine unit impounded by the McKinney basalt in the Snake River Canyon near Bliss, Idaho. In: Bonnichsen B, Breckenridge R (eds) Cenozoic Geology of Idaho. Ida Bur Mines Geol Bull 26, pp 617-628

Malde HE, Powers HA (1962) Upper Cenozoic stratigraphy of western Snake River Plain, Idaho. GSA Bull 73(10):1197-1220. https:// doi.org/10.1130/00167606(1962)73[1197:UCSOWS]2.0.CO;2

Martinez PA, Marti DA, Molina WF, Bidau CJ (2013) Bergmann's rule across the Equator: a case study in Cerdocyon thous (Canidae). J Anim Ecol 82(5):997-1008. https://doi.org/10.1111/1365-2656. 12076

McDonald HG (1993) More than just horses Hagerman Fossil Beds: Hagerman, Idaho. Rocks Miner 68(5):322-326. https://doi.org/ $10.1080 / 00357529.1993 .9926562$
McDonald HG (2020) Late Miocene to Late Pliocene (Hemphillian to Blancan) borophagine canids (Mammalia: Carnivora) from Idaho. West N Am Nat 80(3):408-425. https://doi.org/10.3398/ 064.080 .0312

Meachen JA, Samuels JX (2012) Evolution in coyotes (Canis latrans) in response to the megafaunal extinctions. Proc Natl Acad Sci USA 109(11):11-16. https://doi.org/10.1073/pnas.1113788109

Meachen JA, Janowicz AC, Avery JE, Sadleir RW (2014) Ecological changes in coyotes (Canis latrans) in response to the ice age megafaunal extinctions. PLoS One 9(12):1-15. https://doi.org/ 10.1371/journal.pone.0116041

Meiri S, Dayan T (2003) On the validity of Bergmann's rule. J Biogeogr 30(3):331-351. https://doi.org/10.1046/j.1365-2699.2003. 00837.x

Meiri S, Dayan T, Simberloff D (2005) Variability and correlations in carnivore crania and dentition. Funct Ecol 19:337-343. https:// doi.org/10.1111/j.1365-2435.2005.00964.x

Miller WE, Carranza-Castañeda O (1998) Late Tertiary canids from central Mexico. J Paleontol 72:546-556. https://doi.org/10.1017/ S002233600002432X

Min KW, Mundil R, Renne PR, Ludwig KR (2000) A test for systematic errors in 40Ar/39Ar geochronology through comparison with $\mathrm{U} / \mathrm{Pb}$ analysis of a 1.1-Ga rhyolite: Geochim Cosmochim Acta 64(1):73-98. https://doi.org/10.1016/S0016-7037(99)00204-5

Montoya P, Morales J, Abella J (2009) Eucyon debonisi n. sp., a new Canidae (Mammalia, Carnivora) from the latest Miocene of Venta del Moro (Valencia, Spain). Geodiversitas 31:709-722. https://doi.org/10.5252/g2009n4a709

Morales J, Pickford M, Soria D (2005) Carnivores from the late Miocene and basal Pliocene of the Tugen Hills, Kenya. Rev Soc Geol Esp 18:39-61

Neville C, Opdyke ND, Lindsay EH, Johnson NM (1979) Magnetic stratigraphy of Pliocene deposits of the Glenns Ferry Formation, Idaho, and its implications for North American mammalian biostratigraphy. Am J Sci 279 (5):503-526. https://doi.org/10. 2475/ajs.279.5.503

Nowak RM (1979) North American Quaternary Canis. Monogr. Mus Nat Hist Univ Kansas 6:1-154. https://doi.org/10.5962/bhl.title.4072

Nowak RM (2002) The original status of wolves in eastern North America. Southeast Nat 1(2):95-130. https://doi.org/10.1656/ 1528-7092(2002)001[0095:TOSOWI]2.0.CO;2

Nowak RM (2003) Wolf evolution and taxonomy. In: Mech LD, Boitani L (eds) Wolves: Behavior, Ecology, and Conservation. University of Chicago Press, Chicago, Illinois, pp 239-258. https://doi.org/ 10.7208/9780226516981-013

Nowak RM, Federoff NEB (2002) The systematic status of the Italian wolf, Canis lupus. Acta Theriol 47(3):333-338. https://doi.org/ 10.1007/BF03194151

Ogg J (2012) Geomagnetic polarity time scale. In: Gradstein FM, Ogg JG, Schmitz MB, Ogg GM (eds) Geologic Time Scale, Elsevier, pp 85-113. https://doi.org/10.1016/B978-0-444-59425-9. 00005-6

O'Keefe FR, Meachen J, Fet EV, Brannick A (2013) Ecological determinants of clinal morphological variation in the cranium of the North American gray wolf. J Mammal 94(6):1223-1236. https:// doi.org/10.1644/13-MAMM-A-069

Perri AR, Mitchell KJ, Mouton A, Álvarez-Carretero S, Hulme-Beaman A, Haile J, Jamieson A, Meachen J, Lin AT, Schubert BW et al. (2021) Dire wolves were the last of an ancient New World canid lineage. Nature 591:87-91. https://doi.org/10.1038/s41586-020-03082-x

Pilot M, Jedrzejewski W, Sidorovich VE, Meier-Augenstein W-M, Hoelze AR (2012) Dietary differentiation and the evolution of population genetic structure in a highly mobile carnivore. PLoS One 7(6): e39341. https://doi.org/10.1371/journal.pone.0039341

Pilot M, Greco C, vonHoldt BM, Randi E, Jędrzejewski W, Sidorovich VE, Konopiński M K, Ostrander EA, Wayne RK (2018) Widespread, 
long-term admixture between grey wolves and domestic dogs across Eurasia and its implications for the conservation status of hybrids. Evol Appl 11(5): 662680. https://doi.org/10.1111/eva.12595

Prassack KA (2016) Lontra weiri, sp. nov., a Pliocene river otter (Mammalia, Carnivora, Mustelidae, Lutrinae) from the Hagerman Fossil Beds (Hagerman Fossil Beds National Monument), Idaho, USA. J Vertebr Paleontol 36(4):e1149075. https://doi.org/10. 1080/02724634.2016.1149075

Prevosti FJ, Tonni EP, Bidegain JC (2009) Stratigraphic range of the large canids (Carnivora, Canidae) in South America, and its relevance to quaternary biostratigraphy. Quat Int 210(1-2):76-81. https://doi.org/10.1016/j.quaint.2009.06.034

Prevosti FJ, Segura V, Cassini GH (2013) Revision of the systematic status of Patagonian and Pampean gray foxes (Canidae: Lycalopex griseus and L. gymnocercus) using 3D geometric morphometrics. Mastozool Neotrop 20:289-300

Pocock RI (1935) The races of Canis lupus. Proc Zool Soc Lond 105:647-686

Repenning CA, Weasma TR, Scott GR (1995) The early Pleistocene (latest Blancan-earliest Irvingtonian) Froman Ferry fauna and history of the Glenns Ferry Formation, southwestern Idaho. Geol Soc Bull 2105. https://doi.org/10.3133/b2105

Rook L (1992) "Canis" monticinensis sp. nov., a new Canidae (Carnivora, Mammalia) from the late Messinian of Italy. B. Soc. Paleontol Ital 31:151-156

Rook L (2009) The wide-ranging genus Eucyon Tedford \& Qiu, 1996 (Mammalia, Carnivora, Canidae, Canini) in the Mio-Pliocene of the old world. Geodiversitas 31(4):723741. https://doi.org/ $10.5252 / \mathrm{g} 2009 \mathrm{n} 4 \mathrm{a} 723$

Rueness EK, Asmyhr MG, Sillero-Zubiri C, Macdonald DW, Bekele A, Atickem A, Stenseth NC (2011) The cryptic African wolf: Canis aureus lupaster is not a golden jackal and is not endemic to Egypt. PLoS One 6(1):e16385. https://doi.org/10.1371/journal.pone. 0016385

Samuels JX, Meachen-Samuels JA, Gensler PA (2009) The first midBlancan occurrence of Agriotherium (Ursidae) in North America: a record from Hagerman Fossil Beds National Monument, Idaho. J Paleontol 83(4):597-603. https://doi.org/10.1666/08-112R.1

Sansalone G, Berte DF, Maiorino L, Pandolfi L (2015) Evolutionary trends and stasis in carnassial teeth of European Pleistocene wolf Canis lupus (Mammalia, Canidae). Quat Sci Rev 110:364-348. https://doi.org/10.1016/j.quascirev.2014.12.009

Sarna-Wojcicki AM (1976) Correlation of Late Cenozoic tuffs in the central coast ranges of California by means of trace and minorelement chemistry. US Geol Surv Prof Pap 972. https://doi.org/ $10.3133 / \mathrm{pp} 972$

Sarna-Wojcicki AM (2000) Tephrochronology. In: Noller JS, Sowers JM, Lettis WR (eds) Quaternary Geochronology: Methods and Applications. Vol 4. American Geophysical Union, Washington, DC, pp 357-377. https://doi.org/10.1029/RF004

Sarna-Wojcicki AM and Davis JO (1991) Quaternary tephrochronology. In: Morrison RB (ed) The Geology of North America, vol. K-2, Quaternary Nonglacial Geology Conterminous U.S. The Geological Society of America, Colorado, pp 93-116. https:// doi.org/10.1130/DNAG-GNA-K2.93

Schiaffini MI, Segura V, Prevosti FJ (2019) Geographic variation in skull shape and size of the pampas fox Lycalopex gymnocercus (Carnivora: Canidae) in Argentina. Mamm Biol 97:50-58. https://doi.org/10.1016/j.mambio.2019.04.001

Schwartz MK, Vucetich JA (2009) Molecules and beyond: assessing the distinctness of the Great Lakes wolf. Mol Ecol 18(11):23072309. https://doi.org/10.1111/j.1365-294X.2009.04177.x

Schweizer RM, Vonholdt BM, Harrigan R, Knowles JC, Musiani M, Coltman D, Novembre J, Wayne RK (2016) Genetic subdivision and candidate genes under selection in North American grey wolves. Mol Ecol 25(1):380-402. https://doi.org/10.1111/mec. 13364

Sillero-Zubiri C, Hoffmann M, Macdonald DW (2004) Canids: foxes, wolves, jackals, and dogs: status survey and conservation action plan. Gland, Switzerland: IUCN

Sinding MHS, Gopalakrishan S, Vieira FG, Samaniego Castruita JA, Raundrup K, Heide Jørgensen MP, Meldgaard M, Petersen B, Sicheritz-Ponten T, Mikkelse, JB, Marquard-Petersen U (2018) Population genomics of grey wolves and wolf-like canids in North America. PLoS Genet 14(11):e1007745. https://doi.org/ 10.1371/journal.pgen.1007745

Slater G, Dumont ER, Van Valkenburgh B (2009) Implications of predatory specialization for cranial form and function in canids. J Zool 278(3):181-188. https://doi.org/10.1111/j.1469-7998. 2009.00567.x

Sotnikova M, Rook L (2010) Dispersal of the Canini (Mammalia, Canidae: Caninae) across Eurasia during the late Miocene to early Pleistocene. Quat Int 212:86-97. https://doi.org/10.1016/j. quaint.2009.06.008

Spassov N, Rook L (2006) Eucyon marinae sp. nov. (Mammalia, Carnivora) a new canid species from the Pliocene of Mongolia, with a review of forms referable to the genus. Riv Ital Paleontol Stratigr 112(1):123. https://doi.org/10.13130/2039$4942 / 5853$

Stoyanov S (2020) Cranial variability and differentiation among golden jackals (Canis aureus) in Europe, Asia Minor and Africa. ZooKeys 917:14. https://doi.org/10.3897/zookeys.917.39449

Strauss RE, Atanasso, MN, De Oliveira JA (2003) Evaluation of the principal-component and expectation-maximization methods for estimating missing data in morphometric studies: J Verter Paleontol 23:284-296. https://doi.org/10.1671/0272-4634(2003) 023[0284:EOTPAE]2.0.CO;2

Tedford RH, Qiu Z (1996) A new canid genus from the Pliocene of Yushe, Shanxi Province. Vertebrat. PalAsiatic 34:27-40

Tedford RH, Wang X, Taylor BE (2009) Phylogenetic systematics of the North American fossil caninae (Carnivora: Canidae). Bull Am Mus Nat Hist 325:1-218. https://doi.org/10.1206/574.1

Van Valkenburgh B (1991) Iterative evolution of hypercarnivory in canids (Mammalia: Carnivora): evolutionary interactions among sympatric predators. Paleobiol 340-362. https://doi.org/10.1017/ S0094837300010691

Van Valkenburgh B, Sacco T (2002) Sexual dimorphism, social behavior, and intrasexual competition in large Pleistocene carnivorans. J Vertebr Paleontol 22(1):164-169. https://doi.org/10.1671/ 02724634(2002)022[0164:SDSBAI]2.0.CO;2

Van Valkenburgh B, Wayne RK (1994) Shape divergence associated with size convergence in sympatric East African jackals. Ecol 75(6):1567-1581. https://doi.org/10.2307/1939618

Van Valkenburgh B, Wang X, Damuth J (2004) Cope's rule, hypercarnivory, and extinction in North American canids. Sci 306(5693):101-104. https://doi.org/10.1126/science.1102417

Viranta S, Atickem A, Werdelin L, Stenseth N Chr (2017) Rediscovering a forgotten canid species. BMC Zool 2:6. https://doi.org/10. 1186/s40850-017-0015-0

vonHoldt BM, Kays R, Pollinger JP, Wayne RK (2016) Admixture mapping identifies introgressed genomic regions in North American canids. Mol Ecol 25(11):2443-2453. https://doi.org/10.1111/mec.13667

Wang X (1994) Phylogenetic systematics of the Hesperocyoninae (Carnivora, Canidae). Bull Am Mus Nat Hist 221:1-207

Wang X, Tedford RH (2007) Evolutionary history of canids. In: Jenson $\mathrm{P}$ (ed) The behavioural biology of dogs. CAB International, Cambridge, pp 3-20

Wang X, Tedford RH, Taylor, BE (1999) Phylogenetic systematics of the Borophaginae (Carnivora: Canidae). Bulletin of the American Museum of Natural History 243:1-391. 
Wang X, Tedford RH, Van Valkenburgh B, Wayne RK (2004) Evolutionary history, molecular systematics, and evolutionary ecology of Canidae. In: Macdonald DW, Sillero-Zubiri C (eds) Biology and conservation of wild canids Oxford University Press, Oxford, United Kingdom, pp 39-54

Waples RS, Kays R, Fredrickson RJ, Pacifici K, Mill LS (2018) Is the red wolf a listable unit under the US Endangered Species Act? J Hered 109(5):585-597. https://doi.org/10.1093/jhered/esy020

Way JG (2013) Taxonomic implications of morphological and genetic differences in northeastern coyotes (coywolves) (Canis latrans $\times$ C. lycaon), western coyotes (C. latrans), and eastern wolves (C. lycaon or C. lupus lycaon). Can Field Nat 127:1-16. https:// doi.org/10.22621/cfn.v127i1.1400

Wayne RK (1986) Cranial morphology of domestic and wild canids: the influence of development on morphological change. Evol 40(2):243261. https://doi.org/10.1111/j.1558-5646.1986.tb00467.x

Werdelin L (1985) Small Pleistocene felines of North America. J Vertebr Paleontol 5(3):194-210. https://doi.org/10.1080/02724634. 1985.10011858

Werdelin L, Lewis ME, Haile-Selassie Y (2015) A critical review of African species of Eucyon (Mammalia; Carnivora; Canidae), with a new species from the Pliocene of the Woranso-Mille area, Afar Region, Ethiopia. Pap Palaeontol 1(1):33-40. https://doi. org/10.1002/spp2.1001

Westgate JA, Gorton MP (1981) Correlation techniques in tephra studies. In: Self S, Sparks RSJ (eds) Tephra Studies, Vol. 75. Springer, Dordrecht pp 73-94. https://doi.org/10.1007/ 978-94-009-8537-7_5

Wilson P, Grewal S, Lawford ID, Heal J, Granacki AG, Pennock D, Theberge JB, Theberge MT, Voigt DR, Waddel W, Chambers RE (2000) DNA profiles of the eastern Canadian wolf and the red wolf provide evidence for a common evolutionary history independent of the gray wolf. Can J Zool 78(12):2156-2166. https://doi.org/10.1139/z00-158

Wroe S, McHenry C, Thomason J (2005) Bite club: comparative bite force in big biting mammals and the prediction of predatory behaviour in fossil taxa. Proc R Soc B Biol Sci 272(1563):619625. https://doi.org/10.1098/rspb.2004.2986

Zrzavý J, Duda P, Robovský J, Okřinová I, Pavelková Řičánková V (2018) Phylogeny of the Caninae (Carnivora): combining morphology, behaviour, genes and fossils. Zool Scr 47:373-389. https://doi.org/10.1111/zsc.12293. 